Biogeosciences, 10, 1-23, 2013

www.biogeosciences.net/10/1/2013/

doi:10.5194/bg-10-1-2013

(c) Author(s) 2013. CC Attribution 3.0 License.

\title{
Nutrient dynamics, transfer and retention along the aquatic continuum from land to ocean: towards integration of ecological and biogeochemical models
}

\author{
A. F. Bouwman ${ }^{1,2}$, M. F. P. Bierkens ${ }^{3,4}$, J. Griffioen ${ }^{4,5,6}$, M. M. Hefting ${ }^{7}$, J. J. Middelburg ${ }^{2}$, H. Middelkoop ${ }^{3}$, and \\ C. P. Slomp ${ }^{2}$ \\ ${ }^{1}$ PBL Netherlands Environmental Assessment Agency, P.O. Box 303, 3720 AH Bilthoven, The Netherlands \\ ${ }^{2}$ Department of Earth Sciences - Geochemistry, Faculty of Geosciences, Utrecht University, P.O. Box 80021, 3508 TA \\ Utrecht, The Netherlands \\ ${ }^{3}$ Department of Physical Geography - Faculty of Geosciences, Utrecht University, P.O. Box 80115, 3508 TC Utrecht, \\ The Netherlands \\ ${ }^{4}$ Deltares, P.O. Box 85467, 3508 AL Utrecht, The Netherlands \\ ${ }^{5}$ Department of Innovation, Environmental and Energy Sciences - Faculty of Geosciences, Utrecht University, P.O. Box \\ 80115,3508 TA Utrecht, The Netherlands \\ ${ }^{6}$ TNO Geological Survey, P.O. Box 80 015, 3508 AL Utrecht, The Netherlands \\ ${ }^{7}$ Ecology and Biodiversity, Department of Biology, Faculty of Natural Sciences, Utrecht University, P.O. Box 800.84, 3508 \\ TB Utrecht, The Netherlands
}

Correspondence to: A. F. Bouwman (lex.bouwman@pbl.nl)

Received: 26 June 2012 - Published in Biogeosciences Discuss.: 19 July 2012

Revised: 16 November 2012 - Accepted: 29 November 2012 - Published: 2 January 2013

\begin{abstract}
In river basins, soils, groundwater, riparian zones and floodplains, streams, rivers, lakes and reservoirs act as successive filters in which the hydrology, ecology and biogeochemical processing are strongly coupled and together act to retain a significant fraction of the nutrients transported. This paper compares existing river ecology concepts with current approaches to describe river biogeochemistry, and assesses the value of these concepts and approaches for understanding the impacts of interacting global change disturbances on river biogeochemistry. Through merging perspectives, concepts, and modeling techniques, we propose integrated model approaches that encompass both aquatic and terrestrial components in heterogeneous landscapes. In this model framework, existing ecological and biogeochemical concepts are extended with a balanced approach for assessing nutrient and sediment delivery, on the one hand, and nutrient in-stream retention on the other hand.
\end{abstract}

\section{Introduction}

Organisms require carbon $(\mathrm{C})$, nitrogen $(\mathrm{N})$, phosphorus $(\mathrm{P})$ and other nutrients such as silicon $(\mathrm{Si})$ for critical cellular processes (Sterner and Elser, 2002). Thus, knowledge of these element cycles is essential for our understanding of ecosystem biogeochemistry. While various elements can limit plant growth at a given place and time, the productivity of most aquatic ecosystems is controlled by the concentration, molecular form, and stoichiometry of the macronutrients N and P (Butcher, 1947; Officer and Ryther, 1980).

Most elements are released on land and transported to the ocean where they are eventually buried in marine sediments. Before reaching the ocean, sediment, organic $\mathrm{C}$ and nutrients from land transit through the continuum formed by soils, groundwater, riparian zones, floodplains, rivers, lakes, estuaries and coastal marine areas. These systems act as successive filters in which the hydrology, ecology and biogeochemical processing are strongly coupled and together act to retain a significant fraction of the nutrients transported (Billen et al., 1991). By affecting primary production, nutrient loads 
impact all other organisms within an ecosystem and thus may strongly determine ecosystem structure (Borum and SandJensen, 1996; Nielsen and Richardson, 1996). Many factors such as temperature, precipitation, or geographic location contribute to the dynamic structure of aquatic ecosystems by affecting nutrients, physical forces, or the organisms themselves.

Retention in the aquatic continuum not only affects the absolute amount of nutrients reaching the ocean, but also modifies the ratio in which $\mathrm{C}, \mathrm{N}, \mathrm{P}$ and $\mathrm{Si}$ are transferred, and the chemical form of each of these elements (Billen et al., 1991; Ensign and Doyle, 2006; Reddy et al., 1999). For example, in aquatic ecosystems, $\mathrm{P}$ is usually less efficiently removed than N (Hejzlar et al., 2009; Billen et al., 1991; Billen and Garnier, 2000; De Wit et al., 2002), while Si retention is enhanced by increasing $\mathrm{N}$ and $\mathrm{P}$ inputs (Conley, 2002). Because river networks link terrestrial landscapes to lakes and oceans, perturbations to river ecosystems can have large consequences for biogeochemical cycling at local, regional, and global scales.

During the past century, human activities have been rapidly changing. Most importantly this has led to increases in energy and food production, use of fertilizer and animal manure, atmospheric deposition of nutrients, and wastewater flows (Stumm, 1973; Galloway et al., 1995). Deforestation and expanding agricultural land use have caused increasing soil erosion and sediment, $\mathrm{C}$ and nutrient transport through river systems (Seitzinger et al., 2010). Land use changes also likely have strongly affected the delivery of Si to rivers (Struyf et al., 2010). Climate change is expected to affect both the hydrology and biogeochemistry of aquatic ecosystems. Increasing $\mathrm{N}$ and $\mathrm{P}$ loading of rivers can enhance rates of photosynthetic and heterotrophic productivity and result in fundamental changes to aquatic food webs (Dodds, 2002; Vollenweider et al., 1992; Cloern, 1996). Global warming is expected to enhance the solubility of particulate silica and increase its availability in aquatic systems (Laruelle et al., 2009). Eutrophication as a result of nutrient loading was first evident in lakes and rivers as they became choked with excessive growth of macrophytes and floating algal scums (Butcher, 1947). Eutrophication of surface waters leads to turbid waters with decreased oxygen levels (hypoxia), toxin production by algae and bacteria, and killing of fish.

Currently, eutrophication negatively affects rivers, lakes, and estuaries worldwide, and accounts for the foremost aquatic ecosystem management problem. This underscores the need to develop approaches to examine interactions among disturbances and to incorporate ecological principles into management and restoration activities (Stanley et al., 2010). Disturbance of biogeochemical cycles by human activities calls for an integrative consideration of biogeochemical fluxes between the atmosphere, terrestrial and aquatic ecosystems. However, such integration of knowledge is hampered by the historical separation between the approaches

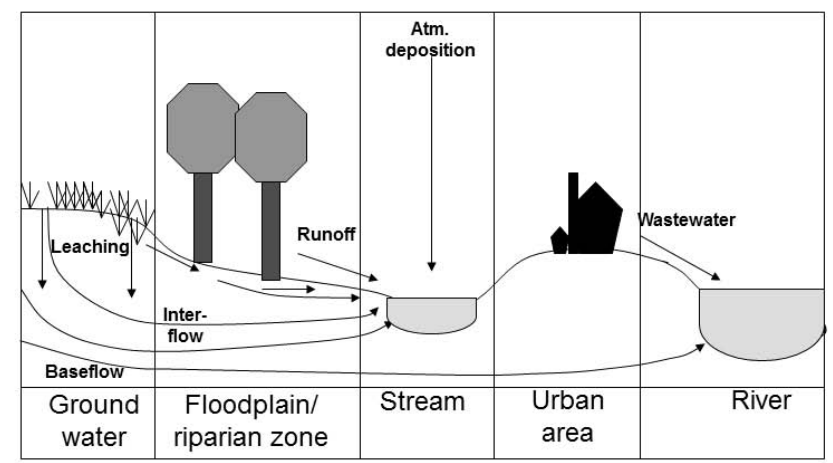

Fig. 1. Schematic of the hydrological system in river basins, including the soil, groundwater, riparian zone and floodplain, and the stream or river, and with wastewater flows from urban areas.

and cultures of terrestrial and aquatic subdisciplines of biogeochemistry.

Models are essential to improve our understanding of the interaction between multiple processes in different landscape elements in river basins (Fig. 1) and to better predict the transfer of nutrients from land to sea in a changing world. Various conceptual models have been developed that differ in their disciplinary rooting and bias, the spatial and temporal domain and resolution, the comprehensiveness of ecosystem coverage and the level of detail of processes that are included. A comparative study of conceptual models for nutrient transfer along the aquatic continuum from land to ocean is, therefore, needed.

This paper compares existing river ecology concepts with current approaches to describe river biogeochemistry, and assesses the value of these concepts and approaches for understanding the impacts of interacting global change disturbances on river biogeochemistry. Readers are cautioned against interpreting this paper as an exhaustive review. Instead, we describe broad themes in research and idea development using examples of representative contributions. These are used to develop a comprehensive, modular model concept for the description of carbon and nutrient biogeochemistry in river basins; this is needed to analyze the impact of multiple disturbances under global change in integrated assessment studies (e.g., Bouwman et al., 2006). We define rivers as the continuum of the hydrological system from soil, groundwater, riparian zones to the main channel with its hyporheic zone, lakes, reservoirs, floodplains and wetlands, but excluding estuaries, deltas and other areas affected by tidal excursion. While we realize that riparian zones and floodplains represent a continuum across the river-land interface, we distinguish between riparian zones with groundwater flows in lower-order streams and floodplains in higherorder rivers with surface flow and sedimentation during highwater stands. 
We first summarize a number of relevant river ecology and hydrogeomorphic concepts (Sect. 2), and compare these with approaches to describe river biogeochemistry (Sect. 3). Section 4 discusses necessary steps forward by extending and improving currently available concepts to develop a model framework that can be used for understanding and predicting impacts of possible future disturbances of river systems.

\section{River ecology and hydrogeomorphic concepts}

Various river ecology concepts have been developed, based on zonation, stream hydraulics, river continuum, nutrient spiraling, serial discontinuity, flood pulse, riverine productivity and catchment hierarchy (Table 1). Other concepts highlight hydrogeomorphic conditions in rivers. Most of these concepts have in common that they emphasize the role of physical processes in ordering biological systems and the role of spatial and temporal scales in understanding these processes (Frissel et al., 1986; Lorenz et al., 1997). We briefly discuss those concepts most relevant to river biogeochemistry.

\subsection{Zonation and river continuum concepts}

The zonation (Huet, 1954) and stream hydraulics (Statzner and Higler, 1986) ecological concepts (Table 1) have been proposed to understand the adaptation of species living in flowing water (lotic) and sediments (benthic) to conditions such as stream flow, roughness, water depth and slope. The river continuum concept (RCC) (Vannote et al., 1980) describes both the structural and functional characteristics of stream communities along the entire length of a river (Table 1). The RCC argues that the biotic stream community adapts its structural and functional characteristics to the abiotic environment, which presents a continuous gradient from headwaters to river mouth. Rivers can roughly be divided into three parts based on stream size: headwaters (Strahler stream orders 1-3), medium-sized streams (orders 4-6) and large rivers (orders $>6$ ). The headwaters of rivers are strongly influenced by riparian vegetation. Primary production is low because of shading, and the vegetation contributes large amounts of allochthonous detritus. Thus, the ratio of gross primary productivity $(P)$ to respiration $(R)$ of the aquatic community is small $(P: R<1)$.

The influence of the riparian zone diminishes while moving downstream; both the importance of terrestrial organic input and the degree of shading decreases, whereas primary production and import of riverine organic matter and organisms from upstream increases. This is reflected by an increase in the $P: R$ ratio. Large rivers receive organic matter, mainly from upstream, which has already been processed. Primary production is often limited by depth and turbidity. Changes in the size of organic matter along the length of the river are reflected in the distribution of functional feeding groups, with collectors and shredders dominating in headwaters, collec- tors and grazers in the middle part of the river, and collectors in lower reaches.

\subsection{Spiraling concept}

The term nutrient spiraling (Table 1) was coined to describe the cycling of nutrients as they are assimilated from the water column into benthic biomass, temporarily retained, and mineralized back into the water column (Webster, 1975). Spiraling is a lumped steady-state model concept where suspended and solution components both are transported and interact with static components such as sediment. The fate of a molecule in a stream is described as a spiral length, which is the average distance a molecule travels to complete a cycle from the dissolved inorganic state in the water column, to a streambed compartment, and eventually back to dissolved inorganic form in the water column (Stream Solute Workshop, 1990). Using this concept, Ensign and Doyle (2006) found that larger streams appear to play an equally important role in buffering downstream ecosystems (lakes, estuaries, and oceans) from nutrient pollution as do headwater streams when considered within the context of stream networks.

\subsection{Telescoping ecosystem model}

In the telescoping ecosystem model (Fisher et al., 1998), streams consist of several subsystems that are spatially distributed concentrically, analogous to the elements of a telescope (Table 1). Subsystems include the central surface stream, vertically and laterally arrayed saturated sediments (hyporheic and parafluvial zones), and the most distal element, the riparian zone. These zones are hydrologically connected; thus water and its dissolved and suspended load move through all of these subsystems as it flows downstream. In any given subsystem, chemical transformations result in a change in the quantity of materials in transport. Processing length, based on the nutrient spiraling concept, is the length of subsystem required to process an amount of substrate equal to advective input. Processing length is specific to the subsystem (e.g., the surface stream), substrate (e.g., nitrate), and process (e.g., denitrification). Disturbance causes processing length to increase. The whole stream-corridor ecosystem consists of several nested cylindrical elements that extend and retract, as would a telescope, in response to disturbance.

\subsection{Serial discontinuity concept}

Dams disrupt the river continuum and cause upstreamdownstream shifts in abiotic and biotic parameters and processes, and the effect is related to the position of the dam along the continuum (Ward and Stanford, 1983). The transport of large organic matter particles will be blocked, thus decoupling the linkage between allochthonous inputs upstream and processing of organic matter downstream (Table 1). Dams also reduce the ecological connectivity between 
Table 1. River ecology concepts for different types of rivers, and aim and dimensions considered.

\begin{tabular}{|c|c|c|c|c|c|}
\hline Concept & River type & Dimension & Main variables & Aim & Reference \\
\hline Zonation & Undisturbed & Longitudinal & $\begin{array}{l}\text { Flow velocity, } \\
\text { temperature }\end{array}$ & $\begin{array}{l}\text { Adaptation of fish } \\
\text { and benthic fauna }\end{array}$ & Huet (1954) \\
\hline $\begin{array}{l}\text { Stream } \\
\text { hydraulics }\end{array}$ & Undisturbed & Longitudinal & $\begin{array}{l}\text { Flow velocity, } \\
\text { water depth, } \\
\text { roughness, slope }\end{array}$ & $\begin{array}{l}\text { Adaptation of } \\
\text { benthic fauna }\end{array}$ & Statzner et al. (1986) \\
\hline $\begin{array}{l}\text { River } \\
\text { continuum }\end{array}$ & $\begin{array}{l}\text { Undisturbed } \\
\text { No floodplain }\end{array}$ & $\begin{array}{l}\text { Longitudinal } \\
\text { based on } \\
\text { Strahler orders } \\
\text { (Strahler, 1952) }\end{array}$ & $\begin{array}{l}\text { Stream size } \\
\text { Energy source } \\
\text { (allochthonous and } \\
\text { autochthonous } \\
\text { organic matter, light } \\
\text { availability) }\end{array}$ & $\begin{array}{l}\text { Organic matter } \\
\text { processing, nutrient } \\
\text { spiraling } P: R \text { ratio }\end{array}$ & Vannote et al. (1980) \\
\hline Spiraling & & Longitudinal & $\begin{array}{l}\text { Flow velocity, } \\
\text { physical retention, } \\
\text { nutrient limitation }\end{array}$ & Nutrient spiraling & $\begin{array}{l}\text { Webster (1975); } \\
\text { Newbold et al. (1981); } \\
\text { Stream Solute Workshop } \\
(1990)\end{array}$ \\
\hline $\begin{array}{l}\text { Telescoping } \\
\text { ecosystem } \\
\text { model }\end{array}$ & & $\begin{array}{l}\text { Longitudinal } \\
\text { (main stream), } \\
\text { lateral and } \\
\text { vertical } \\
\text { arrayed, } \\
\text { includes } \\
\text { riparian zone }\end{array}$ & $\begin{array}{l}\text { Water flow, } \\
\text { substrate process }\end{array}$ & $\begin{array}{l}\text { Nutrient spiraling, } \\
\text { filtration capacity } \\
\text { using processing } \\
\text { length }\end{array}$ & Fisher et al. (1998) \\
\hline Catchment & $\begin{array}{l}\text { Whole } \\
\text { catchment }\end{array}$ & $\begin{array}{l}\text { Catchment, } \\
\text { several } \\
\text { spatiotemporal } \\
\text { scales }\end{array}$ & $\begin{array}{l}\text { Regional } \\
\text { biogeoclimatic } \\
\text { landscape } \\
\text { classification }\end{array}$ & Nutrient cycling & Frissel et al. (1986) \\
\hline Flood pulse & Large floodplain & Lateral & $\begin{array}{l}\text { Duration, frequency, } \\
\text { timing of flood } \\
\text { pulses }\end{array}$ & $\begin{array}{l}\text { Hydrological impact } \\
\text { on biota in floodplains }\end{array}$ & Junk et al. (1989) \\
\hline $\begin{array}{l}\text { Serial } \\
\text { discontinuity }\end{array}$ & $\begin{array}{l}\text { Impounded or } \\
\text { floodplain }\end{array}$ & Longitudinal & Position of dam & $\begin{array}{l}\text { Organic matter } \\
\text { processing and shifts } \\
\text { up and downstream }\end{array}$ & Ward and Stanford (1983) \\
\hline $\begin{array}{l}\text { Riverine } \\
\text { productivity }\end{array}$ & $\begin{array}{l}\text { Well-developed } \\
\text { riparian zone }\end{array}$ & Lateral & $\begin{array}{l}\text { Type and density } \\
\text { of riparian zone, } \\
\text { flow velocity }\end{array}$ & $\begin{array}{l}\text { Primary production, } \\
\text { processing or organic } \\
\text { matter }\end{array}$ & Thorp and Delong (1994) \\
\hline $\begin{array}{l}\text { Connectivity, patch } \\
\text { dynamics }\end{array}$ & Temporary & & & & $\begin{array}{l}\text { Stanley et al. (1997); } \\
\text { Sanzone et al. (2003); } \\
\text { Reid et al. (2008); } \\
\text { Larned et al. (2007); } \\
\text { McIntyre et al. 2009) }\end{array}$ \\
\hline $\begin{array}{l}\text { River ecosystem } \\
\text { synthesis }\end{array}$ & $\begin{array}{l}\text { Undisturbed } \\
\text { and disturbed }\end{array}$ & $\begin{array}{l}\text { Longitudinal } \\
\text { and lateral }\end{array}$ & $\begin{array}{l}\text { Various abiotic } \\
\text { and biotic patches }\end{array}$ & $\begin{array}{l}\text { Functional process } \\
\text { zones resulting from } \\
\text { physiochemical habitat } \\
\text { differences }\end{array}$ & Thorp et al. (2006) \\
\hline $\begin{array}{l}\text { Hydrogeomorphic } \\
\text { frameworks }\end{array}$ & $\begin{array}{l}\text { Undisturbed } \\
\text { and disturbed }\end{array}$ & $\begin{array}{l}\text { River } \\
\text { landscapes }\end{array}$ & $\begin{array}{l}\text { Flow regime, quan- } \\
\text { tity and type/size of } \\
\text { sediment delivered to } \\
\text { the channel, and topo- } \\
\text { graphic setting }\end{array}$ & $\begin{array}{l}\text { Sequence of geomorphic } \\
\text { types and location } \\
\text { of transitions along } \\
\text { drainage systems }\end{array}$ & $\begin{array}{l}\text { Several, e.g., Poole (2002); } \\
\text { Church (2002). }\end{array}$ \\
\hline
\end{tabular}

Extended from Lorenz et al. (1997). 
the mainstream channel and the riparian zone. Dam building is frequently associated with river regulation, which isolates river channels from their floodplain and riparian forest.

\subsection{Flood pulse concept}

Large floodplain rivers are significantly influenced by regular floods of the main river stream into the bordering floodplains. The flood pulse concept (Junk et al., 1989) describes the effects of floods on both the river channel and its floodplain in an unmodified, large river-floodplain system (Table 1). Nutrients originate mainly from river water. Release and storage of nutrients in the floodplain depend on the flood cycle, vegetation cover and its growth cycle. During floods a layer of sediment, composed of nutrients and particulate organic matter and minerals, is deposited on the floodplain. The flood pulse affects the primary production and respiration in the floodplain by determining the occurrence, life cycle and abundance of organisms. Furthermore, the change between the terrestrial and aquatic phase accelerates the decomposition of organic material. The life cycles of biota using floodplain habitats are related to the flood pulse in terms of its annual timing, duration and rate of rise and fall. Peaks in water flow alter the in-stream biogeochemical processes not only by accelerating advection but also by changing the boundary conditions for the system. At high flow rates, stream biogeochemistry is largely controlled by allochthonous sediment, C and nutrient inputs transported from upstream sources, and the whole benthic community may be disrupted by flood events.

\subsection{Catchment concept}

The catchment concept (Frissel et al., 1986) is a hierarchical framework for stream habitat classification, emphasizing the relationships between a stream to its watershed across a wide range of scales in space and time, from the entire channel network to pools, ripples and microhabitats (Table 1). Petts (1994) integrated state of the art research on the functioning of river systems into five principles. Rivers are (i) three dimensional systems, (ii) driven by hydrology and fluvial geomorphology, (iii) structured by food webs, (iv) characterized by spiraling processes, and (v) dependent upon change, i.e., changing flows, moving sediments and shifting channels.

\subsection{River ecosystem synthesis}

In contrast with a common view of rivers as continuous, longitudinal gradients in physical conditions, the river ecosystem synthesis (Thorp and Delong, 1994) is a framework for understanding both broad, often discontinuous patterns along longitudinal and lateral dimensions of river networks and local ecological patterns across various temporal and smaller spatial scales (Table 1). This framework combines ecogeomorphology (ecological aspects of fluvial geomorphology) with a terrestrial landscape model describing hierarchical patch dynamics, including nested, discontinuous hierarchies of patch mosaics with (i) ecosystem dynamics as a composite of intra- and inter-patch dynamics, (ii) linked patterns and processes; (iii) dominance of non-equilibrium and stochastic processes, and formation of a quasi-equilibrium, metastable state.

\subsection{Hydrogeomorphic frameworks}

Merging concepts of patch dynamics and hierarchy theory with existing river ecology concepts is a major challenge in developing improved understanding of fluvial landscapes. Geomorphic type and the extent, shape and spatial arrangement of habitat patches affect surface-subsurface exchange processes, nutrient cycling and biodiversity in rivers (Malard et al., 2002). A hierarchical patch dynamics perspective (Poole, 2002) can be used as a framework for analyzing the interactions between structure and function in fluvial landscapes. Such a framework can be used to describe several aspects including hierarchy, directionality, heterogeneity and interacting processes across spatial scales; in addition, such an approach to river ecology can help to address spatiotemporal linkages between river ecology concepts such as the river continuum, serial discontinuity, flood pulse, and connectivity and patch dynamics concepts.

Geomorphic thresholds in rivers are set by the conditions that govern river channel process and form, including flow regime, quantity and type of sediment delivery, and the channel gradient (Church, 2002). Thresholds determine changes in processes and morphology and delimit distinctive riverine landscapes and habitats.

\section{Integrating river ecology and biogeochemistry concepts}

Rivers are often erroneously discussed as being either a single channel of flowing water or as the main channel plus river floodplains (Thorp et al., 2006). Most ecological concepts (Sect. 2) fail to describe how nutrients and sediments are delivered to streams and rivers through weathering, leaching from soils, transport through groundwater and riparian areas and denitrification therein, and erosion. Except for the telescoping model, the concepts do not include the vertical dimension, i.e., the continuum of upland soil, groundwater, riparian zone, and hyporheic zone (Ward et al., 2001), particularly with respect to the flows of water and nutrients therein.

Biogeochemistry is an integrative discipline. However, terrestrial and aquatic subdisciplines have developed somewhat independently of each other due to physical and biological differences between aquatic and terrestrial ecosystems and because of differences in research traditions between terrestrial and aquatic ecologists (Grimm et al., 2003; Rip and McCann, 2011; Stergiou and Browman, 2005). Many different approaches for describing biogeochemical processes in the 
Table 2. Processes responsible for retention and delivery of sediment, carbon $(\mathrm{C})$, nitrogen $(\mathrm{N})$, phosphorus $(\mathrm{P})$, and silicon $(\mathrm{Si})$ to streams, by form ${ }^{\mathrm{a}}$, and the scale at which these processes occur.

\begin{tabular}{|c|c|c|c|c|c|c|c|}
\hline \multirow[t]{2}{*}{ Process } & \multicolumn{5}{|c|}{ Component } & \multicolumn{2}{|c|}{ Scale } \\
\hline & Sediment & $\mathrm{C}$ & $\mathrm{N}$ & $\mathrm{P}$ & $\mathrm{Si}$ & Temporal & Spatial \\
\hline Weathering & & DIC & & DIP & DSi & Years & Landscape \\
\hline Leaching & & $\begin{array}{l}\text { DIC, } \\
\text { DOC }\end{array}$ & DIN & $\begin{array}{l}\text { DIP, } \\
\text { DOP }\end{array}$ & & Month/season & Plot/landscape \\
\hline Groundwater retention & & $\begin{array}{l}\text { DIC, } \\
\text { DOC }\end{array}$ & DIN & $\begin{array}{l}\text { DIP, } \\
\text { DOP }\end{array}$ & & $\begin{array}{l}\text { Season/year/ } \\
\text { decade }\end{array}$ & Aquifer \\
\hline Groundwater discharge & & $\begin{array}{l}\text { DIC, } \\
\text { DOC }\end{array}$ & DIN & $\begin{array}{l}\text { DIP, } \\
\text { DOP }\end{array}$ & & $\begin{array}{l}\text { Season/year/ } \\
\text { decade }\end{array}$ & Aquifer \\
\hline $\begin{array}{l}\text { Floodplain and riparian } \\
\text { zone processes (exchange, } \\
\text { retention) }\end{array}$ & DIC, DOC & DIN & $\begin{array}{l}\text { DIP, } \\
\text { DOP }\end{array}$ & & Season & $\begin{array}{l}\text { Floodplain/ } \\
\text { riparian zone }\end{array}$ & \\
\hline Erosion/surface runoff & $\begin{array}{l}\text { Soil particles with } \\
\text { attached } \mathrm{C}, \mathrm{N}, \mathrm{P}\end{array}$ & $\mathrm{PC}$ & PN & PP & $\mathrm{ASi}$ & Day or less & Plot/landscape \\
\hline $\begin{array}{l}\text { Wastewater discharge, } \\
\text { aquaculture }\end{array}$ & & $\begin{array}{l}\text { DOC, } \\
\text { PC }\end{array}$ & $\begin{array}{l}\text { DIN, } \\
\text { DON, } \\
\text { PN }\end{array}$ & $\begin{array}{l}\text { DIP, } \\
\text { DOP, } \\
\text { PP }\end{array}$ & DSi & $\begin{array}{l}\text { Constant flow/ } \\
\text { season }\end{array}$ & Local \\
\hline Atmospheric deposition & $\begin{array}{l}\text { Soil particles with } \\
\text { attached } \mathrm{C}, \mathrm{N}, \mathrm{P}\end{array}$ & $\mathrm{PC}$ & DIN & $\mathrm{PP}$ & & Seasonal & Landscape \\
\hline $\begin{array}{l}\text { In-stream retention } \\
\text { including floodplains }\end{array}$ & $\begin{array}{l}\text { Sediment with } \\
\text { attached } \mathrm{C}, \mathrm{N} \text { and } \mathrm{P}\end{array}$ & $\begin{array}{l}\text { PC, } \\
\text { DIC, } \\
\text { DOC }\end{array}$ & $\begin{array}{l}\mathrm{PN}, \\
\mathrm{DIN}, \\
\mathrm{DON}\end{array}$ & $\begin{array}{l}\text { PP, DIP, } \\
\text { DOP }\end{array}$ & $\begin{array}{l}\mathrm{DSi}, \\
\mathrm{ASi}\end{array}$ & Day to season & Plot/landscape \\
\hline $\begin{array}{l}\text { Retention in lakes } \\
\text { and reservoirs }\end{array}$ & $\begin{array}{l}\text { Sediment with } \\
\text { attached } \mathrm{C}, \mathrm{N} \text { and } \mathrm{P}\end{array}$ & $\begin{array}{l}\text { PC, } \\
\text { DIC, } \\
\text { DOC }\end{array}$ & $\begin{array}{l}\text { PN, } \\
\text { DIN, } \\
\text { DON }\end{array}$ & $\begin{array}{l}\text { PP, DIP, } \\
\text { DOP }\end{array}$ & $\begin{array}{l}\mathrm{DSi} \\
\mathrm{ASi}\end{array}$ & $\begin{array}{l}\text { Sediments: permanent; } \\
\text { other compounds: } \\
\text { variable }\end{array}$ & \\
\hline
\end{tabular}

a DIC, DIN, DIP = dissolved inorganic C, N, P; DOC, DON, DOP = dissolved organic C, N, P; PC, PN, PP = particulate C, N, P. DSi = dissolved silica; ASi = amorphous silica

terrestrial and aquatic components of river systems exist, operating at different scales (Table 2; Fig. 2a and b). These approaches range from simple lumped source-transport models that reflect aggregate nutrient-related processes at the scale of river basins using empirical functions, to distributed models based on the spiraling concept, and detailed mechanistic models, which simulate multiple components of the nutrient cycles (Fig. 2b; Table 3).

There are various examples of approaches that reflect lumped, aggregate nutrient-related processes within a river basin (Table 3; Fig. 3a) in a few parameters in simple, often statistical models (Meybeck, 1982; Peierls et al., 1991; Howarth et al., 1996; Seitzinger et al., 2005; Mayorga et al., 2010). Other hybrid approaches such as SPARROW (SPAtially Referenced Regression On Watershed attributes (Smith et al., 1997)) expand on conventional regression methods by using a mechanistic model structure in correlating measured nutrient fluxes in streams with spatial data on nutrient sources and landscape characteristics. All these methodologies work at the seasonal scale at best. The lumped river export models consider sources and sinks to be homogeneously distributed in space, and do not separate terrestrial filters from in-stream loss processes. Regression approaches have in common that they rarely account for nonlinear interactions between sources and loss processes, which makes them less useful for assessing the complex interactions induced by disturbance. Moreover, systems may evolve from a source to a sink depending on the forcing and history (Turner et al., 2008; Cox et al., 2009).

Detailed models for nutrient delivery may be combined with in-stream biogeochemistry described with a simple retention coefficient (Van Drecht et al., 2003), or relationships between the hydraulic load of rivers and retention (e.g., Behrendt and Opitz, 1999). River biogeochemistry as represented by retention is often used as a calibration coefficient, in order to match model results for delivery with observed river water concentrations (e.g., Grizzetti et al., 2008; Hejzlar et al., 2009).

It is not surprising that some approaches are based on the ecological concepts presented in Sect. 2. Following the telescoping model (Fisher et al., 1998), such approaches combine the hydrological water flow as a medium for transport and biogeochemical processing (e.g., Sferratore et al., 2005; Loos et al., 2009; de Wit, 2001). Following the zonation and stream hydraulics concepts, these approaches are distributed, based on a hydrological model, whereby the water flux and 

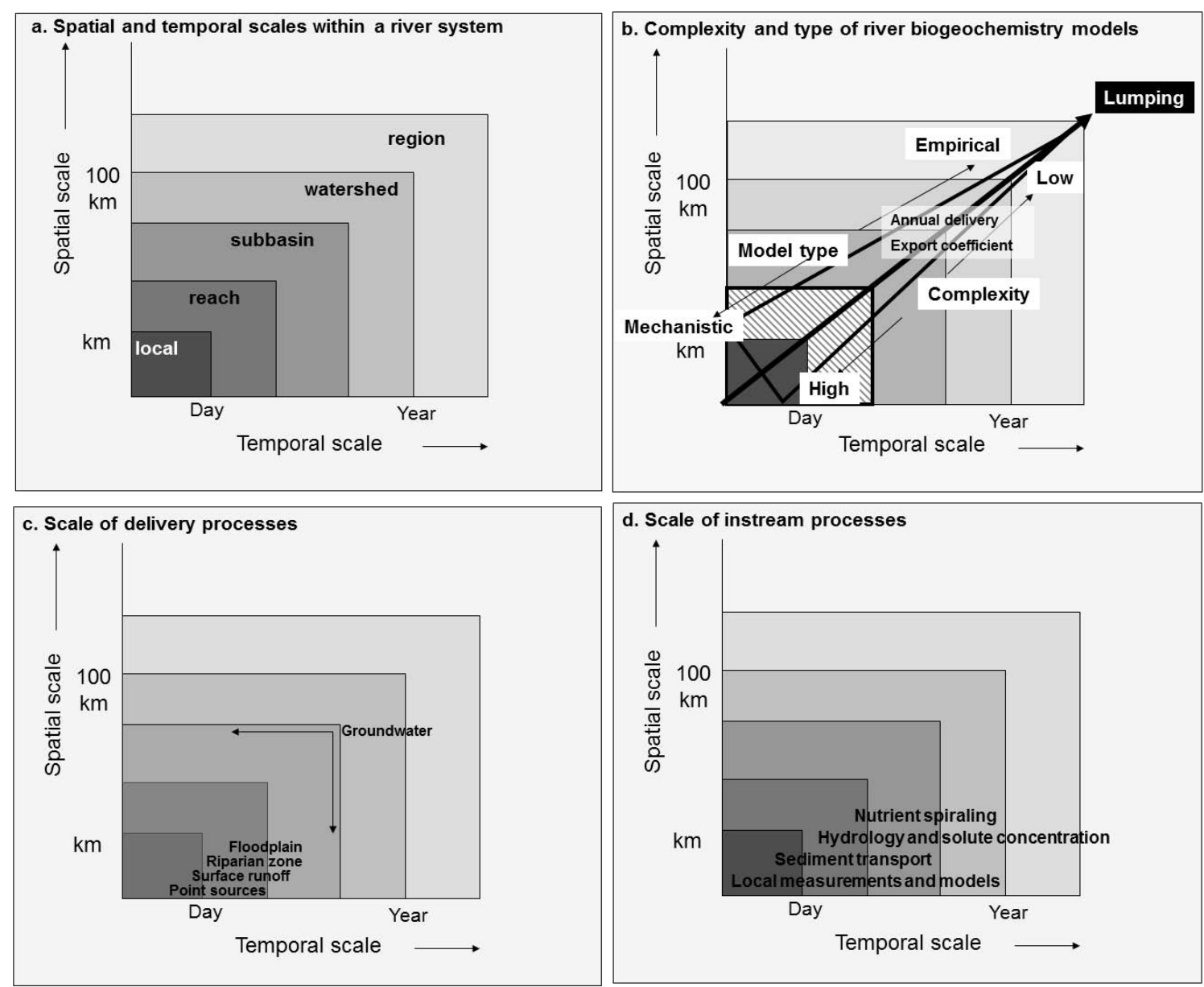

Fig. 2. Scheme of spatial and temporal scales (a) within a river system, (b) complexity and type of model within these domains, increasing complexity of models when moving from the top right to the bottom left corner; lumped models with annual time scale are in the top right corner, and mechanistic models with a time step of days or less in the bottom left corner, (c) the scale of delivery and (d) the scale of in-stream processes.

nutrients therein are partitioned into surface runoff, and flow through the soil to groundwater, riparian zones and surface water as depicted in Figure 1.

In order to stratify the river according to the longitudinal river continuum concept based on stream size, the river network can be subdivided into reaches, for example based on Strahler orders (Strahler, 1952). Strahler stream ordering is also used in estimates of sediment yield per unit area, which generally decreases with increasing catchment area, except for rivers where channel bank erosion is the dominant source of sediment (Walling, 1983; Richards, 1993). Stream ordering allows an understanding and underpinning of the empirically derived value of the exponents, as well as the relative contributions of hillslope sediment delivery and channel bank erosion (Prosser et al., 2001). Many biogeochemical processes such as water-air exchange and gas saturation states scale with river order; Strahler orders are consequently often used in global upscaling procedures (Downing et al., 2012; Raymond et al., 2012).
Subdividing river stream networks allows for applying the spiraling concept (see e.g., Ensign and Doyle, 2006), thus arriving at an elaboration of the catchment concept (Petts, 1994). The spiral length consists of two parts: the uptake length, which is the distance travelled in dissolved form, and the turnover length, which is the distance travelled within the benthic compartment. Usually, uptake length is much longer than turnover length. Uptake length is generally evaluated empirically at the reach scale (Stream Solute Workshop, 1990), with nutrient enrichment experiments, following nutrient decay downstream from a point-source, or with transport-based analysis (various references in Ensign and Doyle, 2006). One of the main limitations of the spiraling concept is that it generally neglects temporal variability in the hydrologic drivers and focuses on baseflow conditions.

Examples of mechanistic models include HSPF (USEPA, 2011; Skahill, 2004), INCA (Whitehead et al., 1998a; Whitehead et al., 1998b), SWAT (Arnold and Fohrer, 2005) and Riverstrahler (Garnier et al., 1995) (Table 3). Such 
Table 3. Examples of available approaches for describing nutrient transport from land to sea through rivers.

\begin{tabular}{|c|c|c|c|c|}
\hline Type & Scale & Approach & Description & Examples \\
\hline Lumped & River basin & $\begin{array}{l}\text { Regression of nutrient } \\
\text { inputs with measured river } \\
\text { export; generally these } \\
\text { models cover one nutrient } \\
\text { species, or several } \\
\text { species-specific regression } \\
\text { models are combined }\end{array}$ & $\begin{array}{l}\text { Describes general relationships } \\
\text { between land processes and river } \\
\text { export; allow for extrapolation } \\
\text { to rivers where measurements of } \\
\text { nutrient export are lacking }\end{array}$ & $\begin{array}{l}\text { Single-species models: Meybeck } \\
\text { (1982); Peierls et al. (1991; May- } \\
\text { orga et al., 2010) Howarth et } \\
\text { al. (1996); range of nutrient } \\
\text { species: Mayorga et al. (2010) }\end{array}$ \\
\hline Hybrid & $\begin{array}{l}\text { Sub-basin to } \\
\text { river basin }\end{array}$ & $\begin{array}{l}\text { Regression combined with } \\
\text { spatially explicit informa- } \\
\text { tion on river basin charac- } \\
\text { teristics }\end{array}$ & & $\begin{array}{l}\text { Smith et al. (1997); Alexander et } \\
\text { al. (2008) }\end{array}$ \\
\hline \multirow[t]{2}{*}{ Distributed } & Reach & $\begin{array}{l}\text { Spiraling approach, based } \\
\text { on transport medium }\end{array}$ & $\begin{array}{l}\text { Considers uptake length (the } \\
\text { distance travelled in dissolved } \\
\text { form) and turnover length (dis- } \\
\text { tance travelled within the ben- } \\
\text { thic compartment) }\end{array}$ & Ensign and Doyle (2006) \\
\hline & Reach & $\begin{array}{l}\text { Mechanistic approach, } \\
\text { based on water flow as } \\
\text { transport medium }\end{array}$ & $\begin{array}{l}\text { Describes algal growth, death } \\
\text { and settling, and decompo- } \\
\text { sition and mineralization to } \\
\text { organic compounds, adsorp- } \\
\text { tion/desorption of particulate } \\
\mathrm{P} \text { on mineral particles, and } \\
\text { denitrification. }\end{array}$ & $\begin{array}{l}\text { HSPF (USEPA, 2011; Skahill, } \\
\text { 2004), INCA (Whitehead et al., } \\
\text { 1998a, b), SWAT (Arnold and } \\
\text { Fohrer, 2005) and Riverstrahler } \\
\text { (Garnier et al., 1995) }\end{array}$ \\
\hline
\end{tabular}

mechanistic models describe algal growth, death and settling, and decomposition and mineralization to organic compounds, adsorption/desorption of particulate $\mathrm{P}$ on mineral particles, and denitrification. Based on the hydrology, these models actually move towards an integration of ecology with hydromorphology (Vaughan et al., 2009) and geomorphology (Thorp et al., 2006) by linking ecology, biogeochemistry and the physical habitat. The complexity of deterministic models often creates intensive data and calibration requirements, which generally limits their application in large watersheds.

The growing availability of digital, high-resolution, spatially and temporally explicit data on climate, elevation, hydrology, vegetation, soils, lakes, wetlands, dams and reservoirs, lithology, aquifers, geology, as well as data on human interventions in river systems, enables us to combine the river ecology concepts in mathematical models and improve existing concepts. For example, while Strahler order number, which is the basis of the river continuum concept, has been used previously as a proxy for watershed dimensions, channel size and stream discharges (Strahler, 1952), we are now able to quantify such properties directly and spatially explicitly, and combine physical properties with those characteristics that are relevant to ecological concepts, such as water chemistry and water temperature (Van Vliet et al., 2011; Van Beek et al., 2011).
Most available models describe one element or a limited number of processes or elements in the river landscape, depending on the discipline of the developers. Models either focus on the delivery processes (Fig. 3b), in-stream processes (Fig. 3c), or disregard landscape elements such as soils, groundwater or riparian zones. In order to understand the impact of human activities that are important for nutrient processing in river basins, and the consequent changes in nutrient export to coastal seas, it is important to extend the existing concepts further with well-balanced approaches.

\section{Towards an integrated model for nutrient transfer from land to ocean}

The above examples show that river ecology concepts have been extremely useful in the development of river biogeochemistry concepts. River models are needed that merge both terrestrial and aquatic aspects (Grimm et al., 2003; Manzoni and Poporato, 2011), including groundwater reservoirs and upland areas (Melles et al., 2012) and wetlands, riparian zones and floodplains (Hattermann et al., 2006). A first attempt is the telescoping ecosystem model (Fisher et al., 1998), which includes the stream and the riparian zone (Table 1). However, this approach needs to be extended with a balanced description of the water flow with sediment, $\mathrm{C}$, and nutrient delivery to streams through the successive filters in 


\section{a. Lumped regression models}

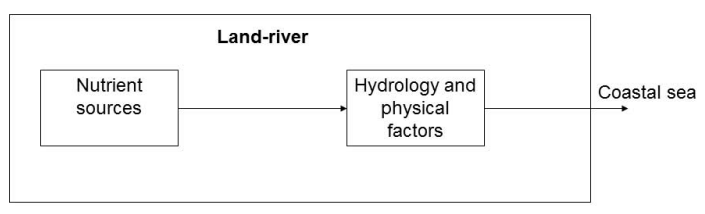

b. Models with focus on delivery processes

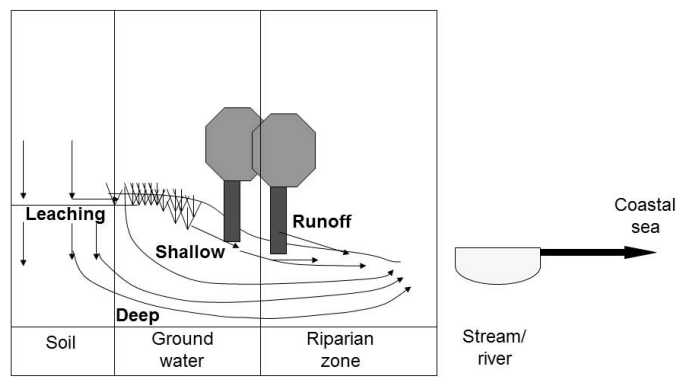

c. Models with focus on in-stream processes

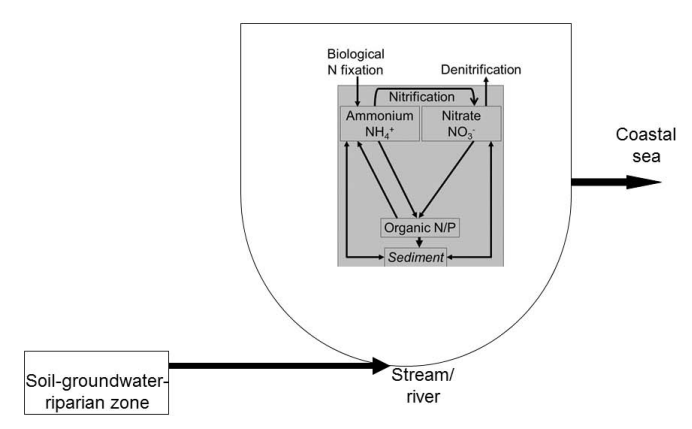

d. Land-river model framework

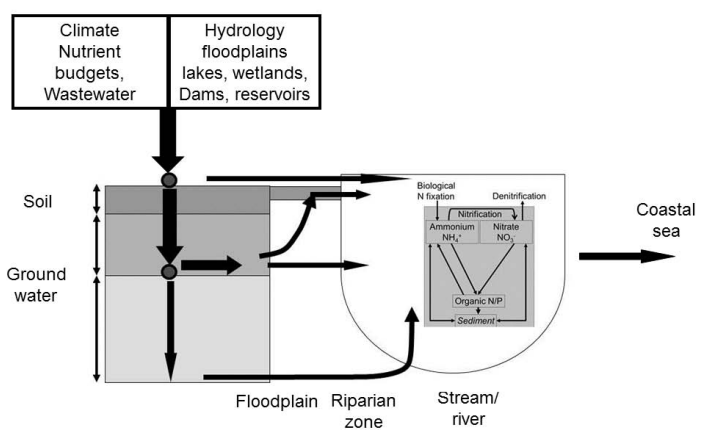

Fig. 3. Schemes for (a) lumped river-basin scale regression models; (b) models with focus on land-based nutrient delivery processes to streams; (c) models with focus on in-stream biogeochemical processes; (d) land-river model framework that adequately accounts for terrestrial and aquatic processes (in Fig. 3c and d, a simplified $\mathrm{N}$ cycle is depicted). the landscape and the stream itself, including lakes, wetlands and reservoirs.

Here, we aim to provide first steps towards a concept for such a river model that adequately accounts for terrestrial and aquatic processes (Fig. 3d). We concentrate on the material flows from below the soil surface to the river mouth, i.e., using information from a dynamic vegetation and agricultural model, and describing the transport and biogeochemical processes of $\mathrm{C}$ and nutrients in the hydrological system of river networks between the soil and the mouth of the river. We also focus on approaches that are applicable at large scales including river basins, continents and the whole globe, and the rich literature on detailed modeling of nutrient exchange between the riverbed and water (e.g., Bardini et al., 2012) will not be covered.

Below, we will subsequently discuss all the elements needed to construct a model that can describe the terrestrial and river filter, i.e., the hydrology (Sect. 4.1), the delivery of dissolved $\mathrm{C}$ and nutrients to streams (4.2), and the in-stream processes (4.3). Riparian zones are considered external and covered in Sect. 4.2, while floodplain processing is considered in-stream processing. We then discuss issues related to the management of a chain of models, data scarcity and uncertainties (Sect. 4.4).

\subsection{Hydrology}

Hydrological water flow provides the medium for transport and biogeochemical processing, via surface runoff or flow through aquifers, streams, lakes, reservoirs and wetlands. Hydrological models focus on the catchment scale, the scale of river basins or larger up to the global scale (Table 4). This development is parallel to the growing availability of databases to parameterize models. Examples include the global HydroSHEDS 90-m drainage network (Lehner et al., 2008), the global database of large dams (Lehner et al., 2011) and the global 1-km soil mapping project (Sanchez et al., 2009).

We foresee that in the coming decade hydrological model lines will converge to hyper-resolution global hydrological models (Wood et al., 2011); such models will describe the integrated hydrological system as a whole at $1 \mathrm{~km}$ resolution or less, involving water and energy fluxes through the series of interconnected bioactive compartments formed by groundwater, soil water, streams, lakes, wetlands, floodplains and reservoirs (Blair et al., 2004), and including water abstraction and human water consumption and with the capacity to model vegetation, crop growth and the cycling and transport of $\mathrm{C}$ and nutrients. This will allow for investigating the important role of mountains in the regional hydrology (Viviroli and Weingartner, 2004), and processes in regions with freeze-thaw cycles and permafrost. The river continuum and flood pulse concepts (Table 1) and floodplain inundation can even be investigated in a spatially explicit manner at the global scale using recent approaches involving water 
Table 4. Hydrological models at different scales

\begin{tabular}{lll}
\hline Scale & Description & Examples \\
\hline Catchment & $\begin{array}{l}\text { Parameterization of within-catchment soil wet- } \\
\text { ness and water redistribution }\end{array}$ & Beven and Kirkby (1979) \\
\hline Catchment to river basin & Semi-distributed integrated models & Abbott et al. (1986) \\
\hline & $\begin{array}{l}\text { Distributed models, combining three- } \\
\text { dimensional variably saturated subsurface } \\
\text { flow with two-dimensional surface flow }\end{array}$ & \\
\hline $\begin{array}{l}\text { River basin to continental (2008); Maxwell (2009) } \\
\text { global to }\end{array}$ & $\begin{array}{l}\text { System theoretical modeling principles (Dooge, } \\
\text { 1973) are applied globally at 1 to 0.5 degree } \\
\text { grids to describe the complete water system in- } \\
\text { cluding groundwater, reservoirs, lakes and hu- } \\
\text { man water abstraction }\end{array}$ & $\begin{array}{l}\text { Arnell (2003); Milly and Schmakin } \\
\text { (2002); Wideín-Nilsson et al. (2007); }\end{array}$ \\
& $\begin{array}{l}\text { Hanasaki et al. (2008); van Beek et } \\
\text { al. (2011) }\end{array}$ \\
\hline & $\begin{array}{l}\text { Hydrology in land surface models of general cir- } \\
\text { culation models (GCM), and vertical water and } \\
\text { energy balance and dynamic vegetation models }\end{array}$ & $\begin{array}{l}\text { Dirmeyer et al. (2006); (Cox et al., } \\
\text { 2000); Sitch et al. (2003); Krinner et } \\
\text { al. (2005) }\end{array}$ \\
\hline
\end{tabular}

flow in all compartments (Van Beek et al., 2011; Yamazaki et al., 2011) (Table 4). Floodplain dynamics are important hydrological features in many large rivers with strong seasonal patterns and not or only slightly affected by human engineering (Blair et al., 2004; McClain and Naiman, 2008; Melack, 2011; Alsdorf et al., 2010).

By extending these models with in-stream biogeochemistry and sediment, $\mathrm{C}$ and nutrient transport (Fig. 3d), river ecology and biogeochemical concepts can be tested and spatiotemporal biogeochemical pathways explicitly resolved for the first time. The single most important condition for this development is that the quality of global rainfall estimates is improved, as errors in rainfall forcing are the largest among the error sources in global hydrological models (Biemans et al., 2009; Sperna Weiland, 2011).

\subsection{Delivery processes}

Delivery processes of sediment and particulate and dissolved $\mathrm{C}$ and nutrients act between the local and reach scale, except for groundwater delivery (Fig. 2c). While the spatial scale for most delivery and in-stream processes varies from local to the reach, the temporal scale varies from days for point sources and surface runoff to days to weeks or months for riparian zones, and from weeks to years for shallow aquifers and years to many years for deep aquifers. To arrive at a realistic estimate of the delivery at one point in time, we need models that describe this multitude of temporal scales for the various pathways of nutrient delivery and processes. Subsequently, we discuss potential model approaches for the delivery of sediment and particulate nutrients to streams (4.2.1), delivery of dissolved organic C and nutrients to aquifers (4.2.2), weathering (4.2.3), biogeo- chemical processes in aquifers and delivery to riparian zones and streams (4.2.4), biogeochemical processes in riparian zones, and delivery to streams (4.2.5) and nutrient delivery in wastewater (4.2.6).

\subsubsection{Delivery of sediment and particulate carbon and nutrients to streams}

While $\mathrm{N}$ and $\mathrm{P}$ delivery show increasing trends as a consequence of human activities, the delivery of $\mathrm{C}$ is not affected or even decreases as a consequence of deforestation. Allochthonous material entering streams ranges from large wood to fine particulate organic matter; it may be old carbon from sedimentary rock recycling to recently fixed carbon (Blair et al., 2004), and it may be broken down locally or transported downstream (Webster et al., 1999). C inputs into a stream, lake or reservoir thus include the POC (particulate organic carbon) transported from upstream, and biomass produced in situ. At the same time, various transformations between particulate, dissolved and gaseous phases may occur during the transport of $\mathrm{C}$ in rivers (e.g., Webster et al., 1999). Numerous factors influence POC and oxidant inputs (that drive POC turnover and preservation), including climate, hydrology, geology, and biota (e.g., Blair et al., 2004). Variations in these environmental parameters lead to changes in POC composition and preservation mechanisms as one moves through the entire system. Allochthonous $\mathrm{C}$ and nutrient inputs entering streams, floodplains and wetlands can be obtained from global dynamic vegetation models (e.g., Sitch et al., 2003).

Turning to sediment production processes, there is large uncertainty regarding the relative contribution of different sediment production processes, i.e., hillslope sediment 
delivery, gully formation, mass movement (slumps) and channel bank erosion (Syvitski et al., 2005). Various approaches with different levels of complexity are generally used to model sediment delivery. Due to the large spatial variation in soil-physical and landscape characteristics, models describing particle detachment and transport require extensive field surveys or substantial calibration, and their application remains limited to hillslopes or smaller catchments (Table 5). Models describing soil loss at the plot and landscape scale need to be extended with re-sedimentation within the landscape, since sediment delivery to streams generally decreases along with travel distance. Predictions at the catchment scale are often based on a sediment delivery ratio (Table 5), i.e., the proportion of the detached sediment that is actually delivered to the channel system.

Lithology, hydrology, relief, climate (storm events), and land use direct these mass-wasting processes that influence the balance between bedrock, soil, and vegetation delivered to waterways and thus the transported amount of POM (particulate organic matter) associated with minerals versus more labile POM not bound to mineral particles (e.g., the conceptual approach of Blair et al., 2004).

Mountains covering only a small fraction of the area of a river basin can supply a large part of the material transported by the river, and thus regulate the ecological characteristics of river reaches and floodplains downstream (e.g., the Amazon; McClain and Naiman, 2008). A recent sediment delivery and transport model was developed for large river basins (Loos et al., 2009). The model approach is mechanistic and spatially explicit with a $3 \times 3 \mathrm{~km}$ resolution and a monthly temporal resolution; it uses global data on terrain elevation, vegetation cover, land use, and soil types to calculate sediment detachment and transport to the stream system. An elaborate version of the model also calculates sediment production by bank erosion, deposition in reservoirs, and conveyance loss due to floodplain sedimentation along the drainage network. Simulation results for large rivers (Rhine, Mississippi, Mekong) range between a factor of 1.2-2 around observed values.

\subsubsection{Delivery of dissolved carbon and nutrients to aquifers}

The movement of dissolved organic carbon (DOC) through soils and aquifers is an important process for the transport of carbon within ecosystems and also the formation of soil organic matter. In some cases, DOC fluxes may also contribute to the $\mathrm{C}$ balance of terrestrial ecosystems; in most ecosystems, they are an important vector of energy, C, and nutrient transfers from terrestrial to aquatic ecosystems (and oppositely for river bank infiltration situations). Despite their importance for aquatic biogeochemistry, these fluxes are rarely represented in conceptual or numerical models of terrestrial biogeochemistry, because they generally represent a small loss term. This is also due to the lack of a comprehensive understanding of the suite of processes that control DOC dynamics.

For the transfer of nutrients from soils, different approaches exist, mainly from agronomic studies. An example of a global-scale approach of the movement of nutrients from soils to surface water via surface runoff and leaching to groundwater is the model of Van Drecht et al. (2003, and the European-scale approach by Velthof et al. (2009), both being summary models based on detailed models. However, no straightforward insight exists on the role of DOC in groundwater denitrification. Siemens et al. (2003) concluded that soil DOC is not an important electron donor in denitrification, whereas Starr and Gillham (1993) and Baker et al. (2000) concluded the opposite. The redox reactivity of DOC thus appears to be location-specific, which is in line with the general observation that the biodegradability and composition of DOC in pore water varies (Qualls and Haines, 1992; Artinger et al., 2000; Maurice et al., 2002). Further work is needed to elucidate the relation between DOC composition and its degradability before accurate predictive modeling is possible.

\subsubsection{Weathering}

Perhaps the most uncertain source of nutrients in rivers is weathering. Weathering is a source of dissolved inorganic carbon, phosphorus and silicon (Table 2), and calcium, magnesium and potassium. Key factors that control chemical weathering processes in the field are, e.g., lithology, runoff, temperature, physical erosion, morphology, soil, ecosystems, land use as well as tectonic activity (various references in Hartmann and Moosdorf, 2011). The influence of each of these factors on chemical weathering processes and rates is well understood and based on laboratory and field research.

Climate has a marked influence on weathering rates, and an increase in temperature and precipitation may increase weathering rates of minerals (Bolt and Bruggenwert, 1976) producing dissolved $\mathrm{Si}, \mathrm{P}$ and alkalinity (Table 2 ). However, factors such as soil age, lithology, runoff and land cover may have a more pronounced effect on weathering rates at the regional to continental scale (Hartmann et al., 2011; White et al., 2005). Tropical river basins play a major role in chemical weathering and transfer of dissolved Si and alkalinity to rivers and oceans due to their geological and climatic settings (Jennerjahn et al., 2006). Because global warming is believed to be especially pronounced at high latitudes in the Northern Hemisphere, a change in structure and cover of vegetation could rapidly alter the hydrology and biogeochemistry of river systems and land-ocean interactions along the coasts of the Arctic Ocean (Humborg et al., 2006). Human-induced land use changes may have similar impacts.

Despite the multitude of existing weathering studies, it is difficult to derive reliable and spatially explicit information on weathering rates and related processes at regional scale. Spatially explicit information on chemical weathering rates 
Table 5. Approaches for describing soil particle detachment, erosion, sediment delivery to streams, channel bank erosion, sediment transport in rivers and sediment trapping in reservoirs.

\begin{tabular}{|c|c|c|}
\hline Process & Description & Examples \\
\hline $\begin{array}{l}\text { Soil particle detachment and } \\
\text { transport }\end{array}$ & $\begin{array}{l}\text { Models for describing detachment of soil particles and } \\
\text { transport by rainfall and overland flow }\end{array}$ & $\begin{array}{l}\text { Morgan et al. (1998); Mor- } \\
\text { gan (2001); Van Rompaey et } \\
\text { al. (2001); Jetten and Favis- } \\
\text { Mortlock (2006) }\end{array}$ \\
\hline Soil erosion & $\begin{array}{l}\text { Spatially distributed physics-based concepts for estimat- } \\
\text { ing overland flow and soil detachment potential, based on } \\
\text { soil characteristics, vegetation cover, tillage and soil mois- } \\
\text { ture status. Transfer functions relating soil types to physi- } \\
\text { cal characteristics are a key component. }\end{array}$ & Kirkby et al. (2004) \\
\hline Sediment delivery ratio (SDR) & $\begin{array}{l}\text { Sediment delivery to streams generally decreases with } \\
\text { longer travel distances of sediment particles; approaches } \\
\text { to estimate SDR are essentially empirical, based on path- } \\
\text { way length, roughness and hill slope, and are calibrated } \\
\text { against observed delivery }\end{array}$ & Van Dijk and Kwaad (1998) \\
\hline Channel bank erosion & $\begin{array}{l}\text { Meander migration rates; bank erosion generally in- } \\
\text { creases with river or catchment size, but with large un- } \\
\text { certainty }\end{array}$ & $\begin{array}{l}\text { Hooke (1980); Lawler (1993); } \\
\text { Van de Wiel (2003) }\end{array}$ \\
\hline Fluvial sediment flow & $\begin{array}{l}\text { Models based on two-dimensional floodplain topography } \\
\text { and vegetation by hydrological model output, and sinks in } \\
\text { reservoirs and floodplains } \\
\text { Physically based approaches include estimates of sedi- } \\
\text { ment transport capacity of specific stream power, channel } \\
\text { slope, roughness and sediment grain size }\end{array}$ & $\begin{array}{l}\text { Doomen et al. (2008); } \\
\text { Prosser and Rustomji (2000) }\end{array}$ \\
\hline Sediment trapping & $\begin{array}{l}\text { Models use observation records and rating curves, or a } \\
\text { drainage basin flux model based on drainage area, relief, } \\
\text { averaged discharge and basin-distributed temperature; } \\
\text { Empirical deterministic approaches have been developed } \\
\text { that relate reservoir trapping efficiency to reservoir stor- } \\
\text { age volume and mean annual input discharge }\end{array}$ & $\begin{array}{l}\text { Syvitski et al. (2005); Walling } \\
\text { (2006); } \\
\text { Verstraeten and } \\
\text { Poesen (2000) }\end{array}$ \\
\hline
\end{tabular}

is essential for river biogeochemistry models. However, extrapolation to areas without monitoring data, but with heterogeneous lithology, is difficult partly because of lack of data for catchments to isolate the influence of above key factors. A further problem in identifying predictors at the regional scale is that relevant potential predictors for weathering rates are often correlated or intimately intertwined. Slope gradient, lithology, runoff, temperature and soil properties are relevant factors to consider for empirical models as proposed by Hartmann and Moosdorf (2011).

\subsubsection{Biogeochemistry in aquifers and delivery to riparian zones and streams}

While transport, weathering and retention processes act at local to reach scale in shallow aquifers, water and solutes may be transported over long distances in deep aquifers (Fig. 2d). Since groundwater travel times may vary from less than one year to millions of years and travel distances may vary from less than $100 \mathrm{~m}$ to more than $1000 \mathrm{~km}$ (Clark and Fritz, 1997; Ingebritsen et al., 2006), it is necessary to simulate the contribution of historical inputs to the groundwater system, and temporary storage and retention processes such as denitrification during transport (Böhlke et al., 2002).

The redox reactivity of DOC in aquifers is locationspecific (see Sect. 4.2.2), and further work is needed to understand and quantify the relative role of dissolved and particulate phases as an electron donor in groundwater systems. This particularly holds for pyrite, which may be more important as an electron donor in denitrification in aquifers than previously thought, particularly in low-lying areas (Postma et al., 1991). Models describing $\mathrm{N}$ transport and denitrification in groundwater at the global (Van Drecht et al., 2003) and European scale (Keuskamp et al., 2012) use the travel time coupled with information on the lithology (Dürr et al., 2005) to estimate the half-life of nitrate in groundwater. 
Aquifers with similar petrographic properties display a similar composition in comparable hydrodynamic and hydrologic environments (Appelo and Postma, 2005). Hydrogeochemical characterization of aquifers as a basis for simulating groundwater composition, weathering, retention processes, and transport could improve the above models; an example is the recent aquifer typology map for 11 European countries (Wendland et al., 2008). Further improvements include the description of the processing of nutrients and of labile dissolved organic C (e.g., Jardine et al., 1992; Lee et al., 2006) and particulate organic $\mathrm{C}$ and pyrite in order to estimate the availability of electron donors for the denitrification process. Continued N loading of groundwater could ultimately lead to depletion of the sediment of electron donors such as pyrite and a more limited attenuation of nitrate in groundwater (Zhang et al., 2009).

The interaction between groundwater and surface water is heterogeneous at various scales, where interaction in the floodplain, riparian and hyporheic zone also plays a role (e.g., Fleckenstein et al., 2006; Sear et al., 1999). It will be impossible to model this complexity in detail at the basin scale. Approaches that deal with the small-scale heterogeneity in a typological way are promising for incorporation in supralocal models (Bertrand et al., 2012; Dahl et al., 2007).

\subsubsection{Biogeochemistry in riparian zones and delivery to streams}

Riparian zones are noted for their nutrient and sediment retention capacity (Ranalli and Macalady, 2010), and have the potential to sequester $\mathrm{C}$ in places where oxygen supply is limited by the stream water thus hampering aerobic decomposition of organic matter (Holden, 2005). Denitrification in riparian buffers is often found to be the major process responsible for $\mathrm{NO}_{3}^{-}$removal from subsurface runoff and groundwater (Hefting et al., 2003). Filtering of sediment from surface runoff and plant uptake from subsurface runoff are the main processes for $\mathrm{P}$ and $\mathrm{NH}_{4}^{+}$retention in these zones (Dorioz et al., 2006; Hoffmann et al., 2009). This filtering capacity of riparian zones is maximized when the depth of the groundwater flow from upland to stream channel is limited by an impermeable or less-permeable subsoil layer at 1-3 m below the soil surface (Hill, 1996). In these situations nutrients and groundwater move through the biologically active topsoil of the riparian zone before reaching the stream (Sabater et al., 2003; Vidon and Hill, 2004a).

A major problem when modeling processes in riparian areas is the lack of spatial detail of data on terrain and hydrogeological conditions. Even maps at the 1:10 000 to 1:20000 scale may have limitations when determining the topography of riparian areas and adjacent upland perimeter slope (Vidon and Hill, 2004b). At such scales the contour interval is $5 \mathrm{~m}$, and riparian areas with less than $5 \mathrm{~m}$ difference in elevation between the upland and riparian area cannot be delineated. Indices that combine surface topographical information with local climatic data, soil maps or groundwater table maps are often used to delineate riparian zones and wetlands (Beven and Kirkby, 1979; Merot et al., 2003; Rodhe and Seibert, 1999; Andersson and Nyberg, 2009). While these indices are generally suitable for areas with hilly topography and shallow soils overlying confined layers, they have shortcomings in more gently sloping terrain (Buttle et al., 2004; Buttle et al., 2001). Emerging technologies such as detailed digital elevation models and high-resolution remote-sensing methods combining laser scanning and hyperspectral imagery (Hall et al., 2009) will be useful to improve the delineation and characterization of riparian zones, and inundation area and depth in floodplains.

Carbon and nutrient transport modeling requires information on the retention time and reactivity within the riparian soil. This largely depends on the local flow path and hydraulic conductivity of the riparian soil layers, information that is available from the hydrology model (Sect. 4.1). Preferential flow paths and bypass flow significantly reduce the nutrient removal capacity (Hefting et al., 2004). A first attempt to simulate the flow of water and dissolved nutrients, and denitrification in riparian zones at the global scale (Bouwman et al., 2012) is a suitable starting point for modeling the riparian filter.

\subsubsection{Delivery of nutrients in wastewater}

Sewage emissions of $\mathrm{N}$ and $\mathrm{P}$ constitute an important source of nutrients in freshwater and coastal marine ecosystems at local, regional, and even global scales (Seitzinger et al., 2010). In the past four to five decades, there have been important changes in sewage $\mathrm{N}$ and $\mathrm{P}$ emissions to surface water in many countries. Nitrogen emissions from sewage have changed because of increasing population and economic growth leading to changes in diet, urbanization, and construction of sewerage and wastewater treatment systems. Emissions of $\mathrm{P}$ from sewage have changed for the same reasons, but also because of changes in patterns of use of Pbased detergents in washing machines for both laundry and dishes. At the global scale, a simple model approach has been developed to describe spatially explicit wastewater contributions to river loading of $\mathrm{N}$ and $\mathrm{P}$ at the national scale (Van Drecht et al., 2009).

Freshwater aquaculture is a further source of emissions to surface water. The global annual production of finfish and shellfish in freshwater aquaculture systems has increased rapidly since the 1950s, particularly in Asia, Europe, North America and South America. Nutrient transformation and release from aquaculture includes many forms of inorganic, organic and particulate nutrients. A simple model to describe all these nutrient emissions to surface water has been developed recently (Bouwman et al., 2011). 


\subsection{In-stream processes}

Subsequently we discuss in-stream biogeochemistry (4.3.1), retention in lakes and reservoirs (4.3.2), bank erosion and sediment transport (4.3.3), floodplain sediment and POC deposition (4.3.4), and nutrient exchange between the stream and the hyporheic zone (4.3.5).

\subsubsection{In-stream biogeochemistry}

The breakdown of leaves, sticks and branches falling into streams is generally near the point where the material enters the stream; the major product is fine particulate organic matter (FPOM), and only a fraction of the organic carbon is converted to $\mathrm{CO}_{2}$ or lost as dissolved organic matter (Webster et al., 1999). Generally streams dominated by allochthonous inputs export more organic material than is metabolized because of the inefficient organic matter processing (Webster and Meyer, 1997). The exported refractory material may be transported over long distances and settle on the bottom of lakes, reservoirs or even oceans. River ecology concepts (e.g., the RCC) generally focus on labile POC, but should be complemented with approaches to describe both labile and mineral-associated POC, such as the conceptual model of Blair et al. (2004).

Parallel and linked to the processing of $\mathrm{C}$, there is algal growth, death and settling, and decomposition, mineralization to organic compounds, adsorption/desorption of particulate $\mathrm{P}$ on mineral particles, and denitrification. In-stream biogeochemical processes (Figure 2d) operate between the local and reach scale. The working unit for the nutrient instream processes of most watershed-scale models is the reach (Marcé and Armengol, 2009); in detailed models the length of a reach could be 10-1000 m, with a representation of channel width and depth. In the other extreme, for example global models with a $5 \times 5 \mathrm{~min}$ or $1 \times 1 \mathrm{~km}$ resolution, the reach is determined by the local drainage direction used for routing of the water flow. At such scales, models describe processes at a scale that is dictated by the aggregation of the data.

Various formulations for biogeochemical reactions are possible, depending on the research question. If the interest is to analyze the combined effect of multiple disturbances, a mechanistic model is needed, such as the Riverstrahler model (Billen and Garnier, 2000). This model allows for analyzing, apart from other disturbances, the impact of changing nutrient load and changing nutrient ratios, and potential saturation of retention processes such as denitrification and $\mathrm{P}$ retention by sediment. If the main research target is to describe the nutrient balance of the system, the in-stream biogeochemistry model can be described with the much simpler reach-scale nutrient spiraling concept (Newbold et al., 1981) (Fig. 2d).

There is an important coupling between biogeochemistry and hydrology through the role of colloidal particles for reactive transport of particularly phosphate (Liu et al., 2011; Pokrovsky and Schott, 2002). So-called dissolved phosphate is frequently bound to Fe-oxide colloids. The settling and coagulation characteristics of such colloids need to be better understood for predictive modeling of nutrient dynamics in surface water. Sorbed species like phosphate can move through the particle-size spectrum on a piggy-back ride as colloids according to a process called colloidal pumping (Stordal et al., 1996; Wen et al., 1997). The settling properties of phosphate alter accordingly, and this phenomenon is therefore more important in upstream than in lowland rivers (Jarvie et al., 2012).

\subsubsection{Retention in lakes and reservoirs}

Wetlands (Jordan et al., 2011), lakes (Venohr et al., 2005) and man-made reservoirs (Harrison et al., 2009) play an important role in the biogeochemistry of river networks. Sediment, $\mathrm{C}$ and nutrient retention in lakes and reservoirs result from a number of processes, including temporary storage in plant biomass, trapping of sediment and particulate $\mathrm{C}, \mathrm{N}$ and P (Beusen et al., 2005), Si (Lauerwald et al., 2012), denitrification (Harrison et al., 2009), and exchange of dissolved $\mathrm{P}$ between sediment and water column (Brett and Benjamin, 2008). Sediment trapping in reservoirs is considered to have a major impact on global sediment transport in rivers. Estimated sediment trapping efficiencies range between $70 \%$ to $100 \%$ for large rivers (Vörösmarty et al., 2003). An important issue to consider is the possible saturation of nutrient retention may occur in lake sediments (Richardson and Qian, 1999) and streams (Bernot and Dodds, 2005). To analyze this, the historical nutrient loading of these systems needs to be accounted for.

Combining sediment and nutrient delivery, transport and trapping provides a challenge in finding a balance between the spatial and temporal scales at which the key processes operate, data availability and quality and computational feasibility (Loos et al., 2009). The description of processes within such water bodies is similar to that of the reach, ranging from simple formulations that resemble the spiraling approach, to mechanistic approaches such as Riverstrahler. Detailed spatially explicit global data on the location and extent of lakes and wetlands are available (Lehner and Döll, 2004), with a recent extension for the world's largest reservoirs (Lehner et al., 2011).

\subsubsection{Bank erosion and sediment transport}

Predictions of bank erosion rates are generally derived from estimates of meander migration rates (Table 5); often the focus is on sedimentation in downstream reservoirs. The next step is to trace the sediment flow along its way through the fluvial system, by combining two-dimensional floodplain topography and vegetation and hydrological model output, and quantification of sinks in reservoirs and floodplains. Estimates of suspended sediment transport are often based on observations, with an uncertainty that ranges from a factor 
of 2 for well-monitored rivers to an order of magnitude for poorly monitored rivers, particularly when peak flow events are poorly represented in the observation record.

\subsubsection{Floodplain sediment and POC deposition}

Floodplains are important features of some of the largest rivers in the world, such as the Amazon. Such floodplains play an important role in the temporary storage of sediment and associated POM (Blair et al., 2004). Deposition on floodplain surfaces and erosion of banks creates a slowly moving solid bed reactor for the processing of the OC (organic carbon), and the length and speed of the reactor will vary throughout the floodplain (Blair et al., 2004). Floodplain deposition can lead to considerable trapping of sediment and POM amounting to $10-40 \%$ of the annual load (e.g., Walling et al., 2003). Current estimates are based on measured conveyance losses (e.g., Lambert and Walling, 1987), deposition measured during post-event surveys (e.g., Middelkoop and Asselman, 1998; Steiger et al., 2003), and modeling studies (Hung, 2011; Middelkoop and Van der Perk, 1998; Nicholas and Walling, 1997). Sediment trapping efficiencies in floodplains depend on - apart from sediment settling rates - water discharge over the floodplain, the inundated floodplain area and depth, and residence time of the flood water. The challenge is therefore to estimate annual sediment deposition per downstream unit of floodplain by deriving these variables from inventories of floodplain embankment and high-resolution digital elevation models in combination with flow characteristics (flow duration, stage, discharge) obtained from the hydrological model (Sect. 4.1).

\subsubsection{Nutrient exchange between the stream and the hyporheic zone}

The hyporheic zone is typically defined as the portion of the alluvial aquifer in which surface water and groundwater mix (Gooseff, 2010). An important paradigm in stream ecology is that surface water downwells into sediments and brings materials to the hyporheic zone where they are often biogeochemically transformed and returned to the surface water in some altered form (e.g., Boulton et al., 2010; Bardini et al., 2012). Less emphasis has been placed on the role of upwelling groundwater on biogeochemical transformations at the surface water-groundwater interface (e.g., Krause et al., 2009). Hydrological exchange between the stream and hyporheic zone mediates transport of products from the biogeochemical activities within the sediments. Hotspots of primary productivity in the surface stream often result from exfiltrating nutrient-rich water. Conversely, infiltrating surface water supplies organic matter and dissolved oxygen to hyporheic invertebrates and microbes, enhancing hyporheic productivity (Boulton et al., 2010). A simple approach for describing hyporheic processes is based on the spiraling concept in the telescoping ecosystem model (Fisher et al., 1998).

\subsection{A recipe for integrated modeling}

Advancement in scientific understanding and increasing computational power has resulted in a plethora of models that describe either in detail the hydrology (Sect. 4.1), the transfer of nutrients from soil to aquatic ecosystems (Sect. 4.2) or the biogeochemical processes within aquatic systems (Sect. 4.3). The relative importance of hydrology, nutrient delivery to streams and in-stream transformation processes in governing nutrient transfer from land to ocean cannot be determined a priori, because it depends on many factors including the loading and speciation of nutrients, the ecosystems within the watershed and the spatial and temporal domain covered. The challenge is to balance the detail in model descriptions for the various processes and systems involved with the availability of knowledge and data (Fig. 3d).

Data availability is a key problem in developing the river biogeochemistry models. Except for a limited number of intensively studied systems, data on the input of nutrients and transfer to the adjacent or downstream compartments in a river basin are scarce. This means that often the sediment, $\mathrm{C}$, and nutrient concentrations at one particular place in the system may be known, for example in the stream, and that the processing and retention in those landscape elements delivering to the stream are not or poorly known. The problem of missing information is not easily solved. A common approach to step over this problem is to use simple, ad-hoc coefficients representing all processes between the soil and the river (Billen et al., 2001), or between the soil and the river mouth (Seitzinger et al., 2010), thus treating the whole landscape or river basin as one filter. While these semi-empirical models may have predictive power at the global scale and for current conditions, they will not suffice for accurate projections. These statistical models lump most processes in poorly constrained coefficients, and changes in system functioning in response to disturbance in hydrology (e.g., climate change) or nutrient input (e.g., policy) will not be reflected in these fixed coefficients and thus model projections. For accurate projections we thus have to include mechanistic process descriptions.

Mechanistic models that incorporate most essential process knowledge in detail for all compartments are not only limited by data availability, but also by computational limitations, in particular when uncertainty analysis needs to be included. Mechanistic models often lack robust measures of uncertainty in model coefficients and predictions, although recent developments for hydrological applications can also be used in biogeochemical models (Raat et al., 2004). Uncertainty analysis of more simple approaches such as the nutrient spiraling concept is much less difficult (Marcé and Armengol, 2009). Sensitivity and identifiability analysis (Brun et al., 2001) during model development can help to analyze the relative importance of the successive delivery and retention processes in the landscape, and determine which are the 
most uncertain parts. Initially, further research would then concentrate on the most uncertain model components.

Detailed sensitivity and model identifiability analysis should together with specific research questions then guide further tailoring of the appropriate model in terms of complexity and temporal and spatial resolution. Detailed models of specific processes at small spatial and short temporal scales should be parameterized to be included in models describing regional- to global-scale transfer of nutrients from land to ocean. This may imply that for some substances more emphasis is given to accurate quantitative description of the hydrology (e.g., transport of water and suspended matter), while for some other materials more model resolution is required to adequately resolve the nutrient transfer from soils to aquatic systems (e.g., phosphorus) or within-stream nutrient processing (e.g., nitrogen).

\section{Conclusions}

River ecology concepts have been extremely useful in the development of river biogeochemistry concepts. River ecology concepts are descriptive, and only few of the approaches are quantitative, such as the spiraling concept and the telescoping model, which is based on the spiraling concept. Water as the transporting agent, and the delivery of sediment, $\mathrm{C}$ and nutrients, is often exogenous to the model approaches.

In most ecological concepts, rivers are considered as either a single channel of flowing water or as the main channel plus river floodplains. In those rivers where lakes, wetlands or man-made reservoirs are part of the network, the retention processes within these water bodies need to be included for quantifying the biogeochemical filter of the river network.

Through merging perspectives, concepts, and modeling techniques, integrated approaches can be developed that encompass both aquatic and terrestrial components in heterogeneous landscapes in a changing world. To study the impact of multiple disturbances, and analyze possible solutions, we need to extend the existing ecological and biogeochemistry concepts with a balanced approach for assessing nutrient and sediment delivery, on the one hand, and nutrient in-stream retention on the other hand. This involves a multitude of disciplines and approaches that merge ecological concepts with those of soil and groundwater hydrology, chemistry and biology.
Acknowledgements. AFB gratefully acknowledges financial support from the Global Environment Facility (GEF), United Nations Environment Programme (UNEP), Intergovernmental Oceanographic Commission of the UNESCO (IOC/UNESCO) and other partners through the UNEP/GEF project "Global Foundations for Reducing Nutrient Enrichment and Oxygen Depletion from Land-based Pollution in Support of Global Nutrient Cycle”. CPS acknowledges support from the European Research Council under the European Community's Seventh Framework Programme for ERC Starting Grant 278364.

Edited by: S. Bouillon

\section{References}

Abbott, M. B., Bathurst, J. C., Cunge, J. A., O’Connel, P. E., and Rasmussen, J.: An introduction to the european hydrological system - systeme hydrologique européen "she", 1 . History and phylosophy of a physically-based distributed modeling system, J. Hydrol., 247, 45-59, 1986.

Alcamo, J., Döll, P., Henrichs, T., Kaspar, F., Lehner, B., Rösch, T., and Siebert, S.: Development and testing the watergap 2 model of water use and availability, Hydrol. Sci., 48, 317-337, 2003.

Alexander, R. B., Smith, R. A., Schwarz, G. E., Boyer, E. W., Nolan, J. V., and Brakebill, J. W.: Differences in phosphorus and nitrogen delivery to the gulf of mexico from the mississippi river basin, Environ. Sci. Tech., 42, 822-830, 2008.

Alsdorf, D., Han, S. C., Bates, P., and Melack, J.: Seasonal water storage on the amazon floodplain measured from satellites, Remote Sens. Environ., 114, 2448-2456, 2010.

Andersson, J.-O. and Nyberg, L.: Using official map data on topography, wetlands and vegetation cover for prediction of stream water chemistry in boreal headwater catchments, Hydrol. Earth Syst. Sci., 13, 537-549, 2009, http://www.hydrol-earth-syst-sci.net/13/537/2009/.

Appelo, C. A. J. and Postma, D.: Geochemistry, groundwater and pollution, 2nd edition, Taylor and Francis, London, 536 pp., 2005.

Arnell, N. W.: Effects of ipcc sres emissions scenarios on river runoff: A global perspective, Hydrol. Earth Syst. Sci., 7, 619641, 2003,

http://www.hydrol-earth-syst-sci.net/7/619/2003/.

Arnold, J. G. and Fohrer, N.: Swat2000: Current capabilities and research opportunities in applied watershed modelling, Hydrol Proc., 19, 563-572, 2005.

Artinger, R., Buckau, G., Geyer, S., Fritz, P., Wolf, M., and Kim, J. I.: Characterization of groundwater humic substances: Influences of sedimentary organic carbon, Appl. Geochem., 15, 97 116, 2000.

Baker, M. A. M., Valett, H. M., and Dahm, C. N.: Organic carbon supply and metabolism in a shallow groundwater ecosystem, Ecology, 81, 3133-3148, 2000.

Bardini, L., Boano, F., Cardenas, M. B., Revelli, R., and Ridolfi, L.: Nutrient cycling in bedform induced hyporheic zones, Geochim. Cosmochim. Ac., 84, 47-61, doi:10.1016/j.gca.2012.1001.1025, 2012.

Behrendt, H. and Opitz, D.: Retention of nutrients in river systems: Dependence on specific runoff and hydraulic load, Hydrobiologia, 410, 111-122, 1999. 
Bernot, M. J. and Dodds, W. K.: Nitrogen retention, removal, and saturation in lotic ecosystems, Ecosystems, 8, 442-453, doi:410.1007/s10021-10003-10143-y, 2005.

Bertrand, G., Goldscheider, N., Gobat, J. M., and Hunkeler, D.: Review: From multi-scale conceptualization to a classification system for inland groundwater-dependent ecosystems, Hydrogeol. J., 20, 5-25, doi:10.1007/s10040-011-0791-5, 2012.

Beusen, A. H. W., Dekkers, A. L. M., Bouwman, A. F., Ludwig, W., and Harrison, J.: Estimation of global river transport of sediments and associated particulate $\mathrm{C}, \mathrm{N}$ and P, Glob. Biogeochem. Cy., 19, GB4S05, doi:10.1029/2004GB002453, 2005.

Beven, K. J. and Kirkby, M. J.: A physically based, variable contributing area model of basin hydrology, Hydrol. Sci. Bull., 24, 43-69, 1979.

Biemans, H., Hutjes, R. W. A., Kabat, P., Strengers, B. J., Gerten, D., and Rost, S.: Effects of precipitation uncertainty on discharge calculations for main river basins, J. Hydrometeorol., 10, 10111025, 2009.

Billen, G., Lancelot, C., and Meybeck, M.: N, p, and si retention along the aquatic continuum from land to ocean, in: Ocean margin processes in global change, edited by: Mantoura, R. F. C., Martin, J. M., and Wollast, R., John Wiley and Sons, New York, 19-44, 1991.

Billen, G. and Garnier, J.: Nitrogen transfers through the seine drainage network: A budget based on the application of the "riverstrahler" model, Hydrobiologia, 410, 139-150, 2000.

Billen, G., Garnier, J., Ficht, A., and Cun, C.: Modeling the response of water quality in the seine river estuary to human activity in its watershed over the last 50 years, Estuaries, 24, 977-993, 2001.

Blair, N. E., Leithold, E. L., and Aller, R. C.: From bedrock to burial: The evolution of particulate organic carbon across coupled watershed-continental margin systems, Mar. Chem., 92, 141-156, 2004.

Böhlke, J.-K., Wanty, R., Tuttle, M., Delin, G., and Landon, M.: Denitrification in the recharge area and discharge area of a transient agricultural nitrate plume in a glacial outwash sand aquifer, Minnesota, Water Resour. Res., 38, 1105, 26 pp., doi:10.1029/2001WR000663, 2002.

Bolt, G. H., and Bruggenwert, M. G. M.: Soil chemistry. A. Basic elements, in: Developments in soil science 5a, Elsevier Scienctific Publishing Company, Amsterdam, 281, 1976.

Borum, J., and Sand-Jensen, K.: Is total primary production in shallow coastal marine waters stimulated by nitrogen loading, Oikos, 76, 406-410, 1996.

Boulton, A. J., Datry, T., Kasahara, T., Mutz, M., and Stanford, J. A.: Ecology and management of the hyporheic zone: Streamgroundwater interactions of running waters and their floodplains, J. North Am. Ben. Soc., 29, 26-40, 2010.

Bouwman, A. F., Kram, T., and Klein Goldewijk, K.: Integrated modelling of global environmental change. An overview of image 2.4, in, Publication 500110002/2006, Netherlands Environmental Assessment Agency, Bilthoven, 228, 2006.

Bouwman, A. F., Pawlowski, M., Liu, C., Beusen, A. H. W., and Overbeek, C. C.: Global hindcasts and future projections of coastal nitrogen and phosphorus loads due to shellfish and seaweed aquaculture, Reviews in Fisheries Science, 19, 331-357, 2011.

Bouwman, A. F., Beusen, A. H. W., Griffioen, J., Van Groenigen, J. W., Hefting, M. M., Oenema, O., Van Puijenbroek, P. J. T.
M., Seitzinger, S., Slomp, C. P., and Stehfest, E.: Global trends and uncertainties in terrestrial denitrification and n2o emissions, Philos. T. R. Soc. Lond., in press, 2012.

Brett, M. T. and Benjamin, M. M.: A review and reassessment of lake phosphorus retention and the nutrient loading concept, Freshwater Biol., 53, 194-211, doi:10.1111/j.13652427.2007.01862.x, 2008.

Brun, R., Reichert, P., and Kunsch, H. R.: Practical identifiability analysis of large environmental simulation models, Water Resour. Res., 37, 1015-1030, 2001.

Butcher, R. W.: Studies in the ecology of rivers: Vii. The algae of organically enriched waters, J. Ecol., 35, 186-191, 1947.

Buttle, J. M., Hazlett, P. W., Murray, C. D., Creed, I. F., Jeffries, D. S., and Semkin, R.: Prediction of groundwater characteristics in forested and harvested basins during spring snowmelt using a topographic index, Hydrol. Proc., 15, 3389-3407, 2001.

Buttle, J. M., Dillonb, P. J., and Eerkes, G. R.: Hydrologic coupling of slopes, riparian zones and streams: An example from the canadian shield, J. Hydrol., 287, 161-177, 2004.

Church, M.: Geomorphic thresholds in riverine landscapes, Freshwater Biology, 47, 541-557, doi:10.1046/j.13652427.2002.00919.x, 2002.

Clark, I. and Fritz, P.: Environmental isotopes in hydrogeology, Lewis Publishers Boca Raton, New York, 1997.

Cloern, J. E.: Phytoplankton bloom dynamics in coastal ecosystems: A review with some general lessons from sustained investigation of san fransisco bay, california, Rev. Geophys., 34, 127-168, 1996.

Conley, D.: Terrestrial ecosystems and the global biogeochemical silica cycle, Global Biogeochem. Сy., 16, 1121, doi:10.1029/2002GB001894, 2002.

Cox, P. M., Betts, R. A., Jones, C. D., Spall, S. A., and Totterdell, I. J.: Acceleration of global warming due to carbon-cycle feedbacks in a coupled climate model, Nature, 408, 184-187, 2000.

Cox, T. J. S., Maris, T., Soetaert, K., Conley, D. J., Van Damme, S., Meire, P., Middelburg, J. J., Vos, M., and Struyf, E.: A macrotidal freshwater ecosystem recovering from hypereutrophication: the Schelde case study, Biogeosciences, 6, 2935-2948, doi:10.5194/bg-6-2935-2009, 2009.

Dahl, M., Nilsson, B., Langhoff, J. H., and Refsgaard, J. C.: Review of classification systems and new multi-scale typology of groundwater-surface water interaction, J. Hydrol., 344, 1-16, doi:10.1016/j.jhydrol.2007.06.027, 2007.

De Wit, M., Behrendt, H., Bendoricchio, G., Bleuten, W., and Van Gaans, P.: The contribution of agriculture to nutrient pollution in three european rivers, with reference to the european nitrates directive, European Water Association (EWA), 19, 2002.

De Wit, M. J. M.: Nutrient fluxes at the river basin scale. I: The polflow model, Hydrol. Proc., 15, 743-759, 2001.

Dirmeyer, P. A., Gao, X., Zhao, M., Oki, T., and Hanasaki, N.: The second global soil wetness project (gswp-2), Bull. Am. Meteorol. Soc., 87, 1381-1397, 2006.

Dodds, W. K.: Freshwater ecology: Concepts and environmental applications, Academic Press, San Diego, 2002.

Döll, P. and Fiedler, K.: Global-scale modeling of groundwater recharge, Hydrol. Earth Syst. Sci., 12, 863-885, doi:10.5194/hess-12-863-2008, 2008.

Dooge, J. C. I.: Linear theory of hydrologic systems, United States Department of AgricultureTechnical bulletin 1468, 1973. 
Doomen, A., Wijma, E., Zwolsman, J. J. G., and Middelkoop, H.: Predicting suspended sediment concentrations in the meuse river using a supply-based rating curve, Hydrol. Proc., 22, 1846-1856, 2008 .

Dorioz, J. M., Wang, D., Poulenard, J., and Trévisan, D.: The effect of grass buffer strips on phosphorus dynamics: A critical review and synthe- sis as a basis for application in agricultural landscapes in france, Agriculture, Ecosyst. Environ., 117, 4-21, 2006.

Downing, J. A., Cole, J. J., Duarte, C. M., Middelburg, J. J., Melack, J. M., Prairie, Y. T., Kortelainen, P., Striegl, R. G., McDowell, W. H., and Tranvik, L. J.: Global abundance and size distribution of streams and rivers, Inland waters, 2, 229-236, doi:10.5268/IW2.4.502, 2012.

Dürr, H. H., Meybeck, M., and Dürr, S.: Lithologic composition of the earth's continental surfaces derived from a new digital map emphasizing riverine material transfer, Global Biogeochem. Cy., 19, GB4S10, doi:10.1029/2005GB002515, 2005.

Ensign, S. H. and Doyle, M. W.: Nutrient spiraling in streams and river networks, J. Geophys. Res., 111, G04009, doi:10.1029/2005jg000114, 2006.

Fisher, S. G., Grimm, N. B., Martí, E., Holmes, R. M., and Jones Jr., J. B.: Material spiraling in stream corridors: A telescoping ecosystem model, Ecosystems, 1, 19-34, 1998.

Fleckenstein, J. H., Niswonger, R. G., and Fogg, G. E.: Riveraquifer interactions, geologic heterogeneity, and low-flow management, Groundwater, 44, 837-852, doi:810.1111/j.17456584.2006.00190.x, 2006.

Frissel, C. A., Liss, W. J., Warren, C. E., and Hurley, M. D.: A hierarchical framework for stream habitat classification: Viewing streams in a watershed context, Environ. Manage.,, 10, 199-214, 1986.

Galloway, J. N., Schlesinger, W. H., Levy III, H., Michaels, A., and Schnoor, J. L.: Nitrogen fixation: Anthropogenic enhancementenvironmental response, Global Biogeochem. Cy., 9, 235-252, 1995.

Garnier, J., Billen, G., and Coste, M.: Seasonal succession of diatoms and chlorophyceae in the drainage network of the seine river: Observations and modeling, Limnol. Oceanogr., 40, 750765,1995

Gooseff, M. N.: Defining hyporheic zones - advancing our conceptual and operational definitions of where stream water and groundwater meet, Geography Compass, 4, 945-955, 2010.

Grimm, N. B., Gergel, S. E., McDowell, W. H., Boyer, E. W., Dent, C. L., Groffman, P., Hart, S. C., Harvey, J., Johnston, C., Mayorga, E., McClain, M. E., and Pinay, G.: Merging aquatic and terrestrial perspectives of nutrient biogeochemistry, Oecologia, 137, 485-501, 2003.

Grizzetti, B., Bouraoui, F., and De Marsily, G.: Assessing nitrogen pressures on european surface water, Global Biogeochem. Cy., 22, GB4023, doi:10.1029/2007gb003085, 2008.

Hall, R. K., Watkins, R. L., Heggem, D. T., Jones, K. B., Kaufmann, P. R., Moore, S. B., and Gregory, S. J.: Quantifying structural physical habitat attributes using lidar and hyperspectral imagery, Environ. Monitor. Assess., 159, 63-83, 2009.

Hanasaki, N., Kanae, S., Oki, T., Masuda, K., Motoya, K., Shirakawa, N., Shen, Y., and Tanaka, K.: An integrated model for the assessment of global water resources - Part 1: Model description and input meteorological forcing, Hydrol. Earth Syst. Sci.,
12, 1007-1025, doi:10.5194/hess-12-1007-2008, 2008.

Harrison, J., Maranger, R., Alexander, R., Giblin, A., Jacinthe, P.A., Mayorga, E., Seitzinger, S., Sobota, D., and Wollheim, W.: The regional and global significance of nitrogen removal in lakes and reservoirs, Biogeochem., 93, 143-157, 2009.

Hartmann, J., Lauerwald, R., Hagedorn, B., and Kempe, S.: Atmospheric co2 consumption by chemical weathering in north america, Geochim. Cosmochim. Ac., 75, 7829-7854, doi:7810.1016/j.gca.2011.7810.7007, 2011

Hartmann, J. and Moosdorf, N.: Chemical weathering rates of silicate-dominated lithological classes and associated liberation rates of phosphorus on the japanese archipelago - implications for global scale analysis, Chem. Geol., 287, 125-157, doi:10.1016/j.chemgeo.2010.12.004, 2011.

Hattermann, F. F., Krysanova, V., Habeck, A., and Bronstert, A.: Integrating wetlands and riparian zones in river basin modelling, Ecol. Modell., 199, 379-392, doi:10.1016/j.ecolmodel.2005.06.012, 2006.

Hefting, M., Clément, J. C., Dowrick, D., Cosandey, A. C., Bernal, S., Cimpian, C., Tatur, A., Burt, T. P., and Pinay, G.: Water table elevation controls on soil nitrogen cycling in riparian wetlands along a european climatic gradient, Biogeochemistry, 67, 113134, 2004.

Hefting, M. M., Bobbink, R., and De Caluwe, H.: Nitrous oxide emission and denitrification in chronically nitrate-loaded riparian buffer zones, J. Environ. Qual., 32, 1194-1203, 2003.

Hejzlar, J., Anthony, S., Arheimer, B., Behrendt, H., Bouraoui, F., Grizzetti, B., Groenendijk, P., Jeuken, M. H. J. L., Johnsson, H., Lo Porto, A., Kronvang, B., Panagopoulos, Y., Siderius, C., Silgram, M., Venohr, M., and Zaloudık, J.: Nitrogen and phosphorus retention in surface waters: An inter-comparison of predictions by catchment models of different complexity, J. Environ. Monitor., 11, 584-593, 2009.

Hill, A. R.: Nitrate removal in stream riparian zones, J. Environ. Qual., 25, 743-755, 1996.

Hoffmann, C. C., Kjaergaard, C., Uusi-Kämppä, J., Bruun Hansen, H. C., and Kronvang, B.: Phosphorus retention in riparian buffers: Review of their efficiency, J. Environ. Qual., 38, 19421955, 2009.

Holden, J.: Peatland hydrology and carbon release: Why small-scale process matters, Philos. T. R. Soc. Lond., 363, 2891-2913, 2005.

Hooke, J. M.: Magnitude and distribution of rates of river bank erosion, Earth Surf. Proc. Land., 5, 143-157, 1980.

Howarth, R. W., Billen, G., Swaney, D., Townsend, A., Jaworski, N., Lajtha, K., Downing, J. A., Elmgren, R., Caraco, N., Jordan, T., Berendse, F., Freney, J., Kudeyarov, V., Murdoch, P., and Zhu Zhao-liang: Regional nitrogen budgets and riverine $\mathrm{n}$ and $\mathrm{p}$ fluxes of the drainages to the north atlantic ocean: Natural and human influences, Biogeochemistry, 35, 2235-2240, 1996.

Huet, M.: Biologie, profils en long et en travers des eaux courantes, Bulletin Francais de Pisciculture, 175, 41-53, 1954.

Humborg, C., Rahm, L., Smedberg, E., Mörth, C.-M., and Danielson, A.: Dissolved silica dynamics in boreal and arctic rivers: Vegetation control over temperature?, in: The silicon cycle, edited by: Ittekot, V., Unger, D., Humborg, C., and Tac An, N., Island Press, Washington, 53-69, 2006.

Hung, N. N.: Sediment dynamics in the floodplain of the mekong delta, vietnam, $\mathrm{PhD}$, Institut für Wasserbau, Universität Stuttgart, Stuttgart, 2011. 
Ingebritsen, S., Sanford, W., and Neuzil, C.: Groundwater in geologic processes, 2nd edition, Cambridge Univeristy Press, 2006.

Jardine, P. M., Dunnivant, F. M., Selim, H. M., and McCarthy, J. F.: Comparison of models for describing the transport of dissolved organic carbon in aquifer columns, Soil Sci. Soc. Am. J., 56, 393-401, 1992.

Jarvie, H. P., Neal, C., Rowland, A. P., Neal., M., Morris, P. N., Lead, J. R., Lawlor, A. J., Woods, C., Vincent, C., Guyatt, H., and Hockenhull, K.: Role of riverine colloids in macronutrient and metal partitioning and transport, along an upland-lowland landuse continuum, under low-flow conditions, Sci. Total Environ., in press, doi:10.1016/j.scitotenv.2011.11.061, 2012

Jennerjahn, T. C., Knoppers, B. A., de Souze, W. F. L., Brunskill, G. J., Silva, E. I. L., and Adi, S.: Factors controlling dissolved silica in tropical rivers, in: The silicon cycle, edited by: Ittekot, V., Unger, D., Humborg, C., and Tac An, N., Island Press, Washington, 29-51, 2006.

Jetten, V., and Favis-Mortlock, D.: Modelling soil erosion in europe, in: Soil erosion in europe edited by: Boardman, J., and Poesen, J., Wiley, doi:10.1002/0470859202.ch50, Chichester, 2006.

Jones, J. P., Sudicky, E. A., and McLaren, R. G.: Application of a fully-integrated surface-subsurface flow model at the watershed-scale: A case study, Water Resour. Res., 44, W03407, doi:10.1029/2006WR005603, 2008.

Jordan, S. J., Stoffer, J., and Nestlerode, J. A.: Wetlands as sinks for reactive nitrogen at continental and global scales: A metaanalysis, Ecosystems, 14, 144-155, 2011.

Junk, J. W., Bayley, P. B., and Sparks, R. E.: The flood pulse concept in river-floodplain systems, in: Canadian Journal Fisheries and Aquatic Sciences Special Publication, International Large River Symposium, 110-127, 1989.

Keuskamp, J. A., van Drecht, G., and Bouwman, A. F.: European-scale modelling of groundwater denitrification and associated n2o production, Environ. Pollut., 165, 67-76, doi:10.1016/j.envpol.2012.02.008, 2012.

Kirkby, M. J., Jones, R. J. A., Irvine, B., Gobin, A., Govers, G., Cerdan, O., Van Rompaey, A. J. J., Le Bissonnais, Y., Daroussin, J., King, D., Montanarella, L., Grimm, M., Vieillefont, V., Puigdefabregas, J., Boer, M., Kosmas, C., Yassoglou, N., Tsara, M., Mantel, S., Van Lynden, G. J., and Huting, J.: Pan-european soil erosion risk assessment: The pesera map, version 1 october 2003. Explanation of special publication ispra 2004 no. 73 (s.P.I.04.73), Office for Official Publications of the European Communities, LuxembourgEuropean Soil Bureau Research Report No. 16, EUR 21176, 18 pp. and 11 map in ISO B11 format, 2004.

Krause, S., Heathwaite, L., Binley, A., and Keenan, P.: Nitrate concentration changes at the groundwater-surface water interface of a small cumbrian river, Hydrol. Proc., 23, 2195-2211, 2009.

Krinner, G., Viovy, N., de Noblet-Ducoudré, N., Ogeé, J., Polcher, J., Friedlingstein, P., Ciais, P., Sitch, S., and Prentice, I. C.: A dynamic global vegetation model for studies of the coupled atmosphere-biosphere system, Global Biogeochemical Cycles, 19, GB1015, doi:10.1029/ 2003GB002199, 2005.

Lambert, C. P., and Walling, D. E.: Floodplain sedimentation: A preliminary investigation of contemporary deposition within the lower reaches of the river culm, devon, uk, Geografiska Annaler, 69A, 393-404, 1987.
Larned, S. T., Datry, T., and Robinson, C. T.: Invertebrate and microbial responses to inundation in an ephemeral river reach in new zealand: Effects of preceding dry periods, Aquatic Sciences: Research Across Boundaries, 69, 554-567, 2007.

Laruelle, G. G., Roubeix, V., Sferratore, A., Brodherr, B., Ciuffa, D., Conley, D. J., Dürr, H. H., Garnier, J., Lancelot, C., LeThiPhuong, Q., Meunier, J. D., Meybeck, M., Michalopoulos, P., Moriceau, B., Ni Longphuirt, S., Loucaides, S., Papush, L., Presti, M., Ragueneau, O., Regnier, P., Saccone, L., Slomp, C. P., Spiteri, C., and Van Cappellen, P.: Anthropogenic perturbations of the silicon cycle at the global scale: Key role of the land-ocean transition, Global Biogeochem. Cy., 23, doi:10.1029/2008GB003267, 2009.

Lauerwald, R., Hartmann, J., Moosdorf, N., Dürr, H. H., and Kempe, S.: Retention of dissolved silica within the fluvial system of the conterminous USA, Biogeochemistry, 1-23, 2012.

Lawler, D. M.: The measurement of river bank erosion and lateral channel change: A review, Earth Surf. Proc. Land., 18, 777-821, 1993.

Lee, M. S., Lee, K. K., Hyun, Y., Clement, T. P., and Hamilton, D.: Nitrogen transformation and transport modeling in groundwater aquifers, Ecol. Modell., 192, 143-159, 2006.

Lehner, B. and Döll, P.: Development and validation of a global database of lakes, reservoirs and wetlands, J. Hydrol., 296, 1-22, 2004.

Lehner, B., Verdin, K., and Jarvis, A.: New global hydrography derived from spaceborne elevation data, Eos, 89, 93-94, 2008.

Lehner, B., Liermann, C. R., Revenga, C., Vörösmarty, C., Fekete, B., Crouzet, P., Döll, P., Endejan, M., Frenken, K., Magome, J., Nilsson, C., Robertson, J. C., Rödel, R., Sindorf, N., and Wisser, D.: High-resolution mapping of the world's reservoirs and dams for sustainable river-flow management, Front. Ecol. Environ., doi:10.1890/100125, 2011.

Liu, J., Liang, X., Yang, J., Ye, Y., Su, M., Nie, Z., and Chen, Y.: Size distribution and composition of phosphorus in the east tiao river, china: The significant role of colloids, J. Environ. Mon., 13, 2844-2850, doi:2810.1039/C2841EM10482A, 2011.

Loos, S., Middelkoop, H., van der Perk, M., and van Beek, R.: Large scale nutrient modelling using globally available datasets: A test for the rhine basin, J. Hydrol., 369, 403-415, 2009.

Lorenz, C. M., Van Dijk, G. M., Van Hattum, A. G. M., and Cofino, W. P.: Concepts in river ecology: Implications for indicator development, Regulated Rivers: Research and Management, 13, 501516, 1997.

Malard, F., Tockner, K., Dole-Olivier, M. J., and Ward, J. V.: A landscape perspective of surface-subsurface hydrological exchanges in river corridors, Freshwater Biol., 47, 621-640, 2002.

Manzoni, S. and Poporato, A.: Common hydrologic and biogeochemical controls along the soil-stream continuum, Hydrol. Proc., 25, 1355-1360, doi:10.1002/hyp.7938, 2011.

Marcé, R. and Armengol, J.: Modeling nutrient in-stream processes at the watershed scale using Nutrient Spiralling metrics, Hydrol. Earth Syst. Sci., 13, 953-967, doi:10.5194/hess-13-953-2009, 2009.

Maurice, P. A., Cabaniss, S. E., Drummond, J., and Ito, E.: Hydrogeochemical controls on the variations in chemical characteristics of natural organic matter at a small freshwater wetland, Chem. Geol., 187, 59-77, 2002. 
Maxwell, R. M.: Coupled surface-subsurface modeling across a range of temporal and spatial scales, Vadose Zone Journal doi:10.2136/vzj2009.0117, 2009.

Mayorga, E., Seitzinger, S. P., Harrison, J. A., Dumont, E., Beusen, A. H. W., Bouwman, A. F., Fekete, B. M., Kroeze, C., and Van Drecht, G.: Global nutrient export from watersheds 2 (news 2): Model development and implementation, Environ. Modell. Software, 25, 837-853, 2010.

McClain, M. E., and Naiman, R. J.: Andean influences on the biogeochemistry and ecology of the amazon river, BioScience, 58, 325-338, 2008.

McIntyre, R. E. S., Adams, M. A., Ford, D. J., and Grierson, P. F.: Rewetting and litter addition influence mineralisation and microbial communities in soils from a semi-arid intermittent stream, Soil Biol. Biochem., 41, 92-101, 2009.

Melack, J.: Biogeochemistry: Riverine carbon dioxide release, Nat. Geosci., 4, 821-822, 2011.

Melles, S. J., Jones, N. E., and Schmidt, B.: Review of theoretical developments in stream ecology and their influence on stream classification and conservation planning, Freshwater Biol., 57, 415-434, 2012.

Merot, P., Squividant, H., Aurousseau, P., Hefting, M., Burt, T., Maitre, V., Kruk, M., Butturini, A., Thenail, C., and Viaud, V.: Testing a climato-topographic index for predicting wetlands distribution along an european climate gradient, Ecol. Modell., 163, 51-71, 2003.

Meybeck, M.: Carbon, nitrogen and phosphorous transport by world rivers, Am. J. Sci., 282, 401-450, 1982.

Middelkoop, H. and Asselman, N. E. M.: Spatial variability of floodplain sedimentation at the event scale in the rhine-meuse delta, The netherlands, Earth Surf. Proc. Land., 23, 561-573, 1998.

Middelkoop, H. and Van der Perk, M.: Modelling spatial patterns of overbank sedimentation on embanked floodplains, Geografiska Annaler, 80A, 95-109, 1998.

Milly, P. C. M. and Schmakin, A. B.: Global modeling of land water and energy balances, Part I: The land dynamics (lad) model, J. Hydrometeorol., 3, 283-299, 2002.

Morgan, R. P. C., Quinton, J. N., Smith, R. E., Govers, G., Poesen, J. W. A., Auerswald, K., Chisci, G., Torri, D., and Styczen, M. E.: The european soil erosion model (eurosem): A dynamic approach for predicting sediment transport from fields and small catchments, Earth Surf. Proc. Land., 23, 527-544, 1998.

Morgan, R. P. C.: A simple approach to soil loss prediction: A revised morgan-morgan-finney model, Catena, 44, 305-322, 2001.

Newbold, J. D., Elwood, J. W., O'Neill, R. V., and Winkle, W. V.: Measuring nutrient spiraling in streams, Can. J. Fish. Aquat. Sci., 38, 860-863, 1981.

Nicholas, A. P. and Walling, D. E.: Modelling flood hydraulics and overbank deposition on river floodplains, Earth Surf. Proc. Land., 22, 59-77, 1997.

Nielsen, E. and Richardson, K.: Can changes in the fisheries yield in the kattegat (1950-1992) be linked to changes in primary production?, ICES J. Mar. Sci., 53, 988-994, 1996.

Officer, C. B. and Ryther, J. H.: The possible importance of silicon in marine eutrophication, Mar. Eco. Prog. Ser., 3, 83-91, 1980.

Oki, T., Agata, Y., Kanae, S., Saruhashi, T., Yang, D., and Musiake, K.: Global assessment of current water resources using total runoff integrating pathways, Hydrol. Sci. J., 46, 983-995, 2001.
Peierls, B. L., Caraco, N. F., Pace, M. L., and Cole, J. C.: Human influence on river nitrogen, Nature, 350, 386-387, 1991.

Petts, G. E.: Rivers: Dynamic components of catchment ecosystems, in: The river handbook. Hydrological and ecological principles, Vol. 2., edited by: Calow, P., and Petts, G. E., Blackwell Scientific Publications, Oxford, 3-22, 1994.

Pokrovsky, O. S. and Schott, J.: Iron colloids/organic matter associated transport of major and trace elements in small boreal rivers and their estuaries (nw russia), Chem. Geol., 190, 141179, 2002.

Poole, G. C.: Fluvial landscape ecology: Addressing uniqueness within the river discontinuum, Freshwater Biol., 47, 641-660, 2002.

Postma, D., Boesen, C., Kristiansen, H., and Larsen, F.: Nitrate reduction in an unconfined sandy aquifer: Water chemistry, reduction processes, and geochemical modeling, Water Resour. Res., 27, 2027-2045, 1991.

Prosser, I. P. and Rustomji, P.: Sediment transport capacity relations for overland flow, Prog. Phys. Geogr., 24, 179-193, 2000.

Prosser, I. P., Rutherford, I. D., Olley, J. M., Young, W. J., Wallbrink, P. J., and Moran, C. J.: Large-scale patterns of erosion and sedimentation transport in river networks, with examples from australia, Mar. Freshw. Res., 52, 81-99, 2001.

Qualls, R. G. and Haines, B. L.: Biodegradability of dissolved organic matter in forest throughfall, soil solution, and stream water, Soil Sci. Soc. Am. J., 56, 578-586, 1992.

Raat, K. J., Vrugt, J. A., Bouten, W., and Tietema, A.: Towards reduced uncertainty in catchment nitrogen modelling: Quantifying the effect of field observation uncertainty on model calibration, Hydrol. Earth Syst. Sci., 8, 751-763, 2004, http://www.hydrol-earth-syst-sci.net/8/751/2004/.

Ranalli, A. J. and Macalady, D. L.: The importance of the riparian zone and in-stream processes in nitrate attenuation in undisturbed and agricultural watersheds: A review of the scientific literature, J. Hydrol., 389, 406-415, 2010.

Raymond, P. A., Zappa, C. J., Butman, D., Bott, T. L., Potter, J., Mulholland, P., Laursen, A. E., McDowell, W. H., and Newbold, D.: Scaling the gas transfer velocity and hydraulic geometry in streams and small rivers, Limnol. Oceanogr., Fluids Environ., 2, 41-53, doi:10.1215/21573689-1597669, 2012.

Reddy, K. R., Kadlec, R. H., Flaig, E., and Gale, P. M.: Phosphorus retention in streams and wetlands: A review, Critical Reviews in Environ. Sci. Techn., 29, 83-146, 1999.

Reid, D. J., Quinn, G. P., Lake, P. S., and Reich, P.: Terrestrial detritus supports the food webs in lowland intermittent streams of south-eastern australia: A stable isotope study, Freshw. Biol., 53, 2036-2050, 2008.

Richards, K.: Sediment delivery and the drainage network, in: Channel network hydrology, edited by: Beven, K. and Kirkby, M. J., Wiley, Chichester, 221-254, 1993.

Richardson, C. J. and Qian, S. S.: Long-term phosphorus assimilative capacity in freshwater wetlands: A new paradigm for sustaining ecosystem structure and function, Environ. Sci. Techn., 33, 1545-1551, doi:10.1021/es980924a, 1999.

Rip, J. M. K. and McCann, K. S.: Cross-ecosystem differences in stability and the principle of energy flux, Ecol. Lett., 14, 733740, 2011.

Rodhe, A. and Seibert, J.: Wetland occurrence in relation to topography: A test of topographic indices as moisture indicators, Agri- 
cultural and Forest Meteorology, 98-99, 325-340, 1999.

Sabater, S., Butturini, A., Clement, J. C., Burt, T., Dowrick, D., Hefting, M., Maître, V., Pinay, G., Postolache, C., Rzepecki, M., and Sabater, F.: Nitrogen removal by riparian buffers along a european climatic gradient: Patterns and factors of variation, Ecosystems, 6, 20-30, 2003.

Sanchez, P. A., Ahamed, S., Carré, F., Hartemink, A. E., Hempel, J., Huising, J., Lagacherie, P., McBratney, A. B., McKenzie, N. J., De Lourdes Mendonça-Santos, M., Minasny, B., Montanarella, L., Okoth, P., Palm, C. A., Sachs, J. D., Shepherd, K. D., Vågen, T. G., Vanlauwe, B., Walsh, M. G., Winowiecki, L. A., and Zhang, G. L.: Digital soil map of the world, Science, 325, 680681, 2009.

Sanzone, D. M., Meyer, J. L., Marti, E., Gardiner, E. P., Tank, J. L., and Grimm, N. B.: Carbon and nitrogen transfer from a desert stream to riparian predators, Oecologia, 134, 238-250, 2003.

Sear, D. A., Armitage, P. D., and Dawson, F. H.: Groundwater dominated rivers, Hydrol. Proc., 13, 255-276, 1999.

Seitzinger, S. P., Harrison, J. A., Dumont, E., Beusen, A. H. W., and Bouwman, A. F.: Sources and delivery of carbon, nitrogen, and phosphorus to the coastal zone: An overview of global news models and their application, Global Biogeochem. Cy., 19, GB4S, doi:10.1029/2004GB002453, 2005.

Seitzinger, S. P., Mayorga, E., Bouwman, A. F., Kroeze, C., Beusen, A. H. W., Billen, G., Van Drecht, G., Dumont, E., Fekete, B. M., Garnier, J., Harrison, J., Wisser, D., and Wollheim, W. M.: Global river nutrient export: A scenario analysis of past and future trends, Global Biogeochem. Cy., 23, doi:10.1029/2009GB003587, 2010.

Sferratore, A., Billen, G., Garnier, J., and Théry, S.: Modeling nutrient (n, p, si) budget in the seine watershed: Application of the riverstrahler model using data from local to global scale, Glob. Biogeochem. Cy., 19, GB4S07, doi:10.1029/2005GB002496, 2005.

Siemens, J., Haas, M., and Kaupenjohann, M.: Dissolved organic matter induced denirtification in subsoils and aquifers?, Geoderma, 113, 253-271, 2003.

Sitch, S., Smith, B., Prentice, J. C., Arneth, A., Bondeau, A., Cramer, W., Kaplan, J. O., Levis, S., Lucht, W., Sykes, M. T., Thonike, K., and Venevsky, S.: Evaluation of ecosystem dynamics, plant geography and terrestrial carbon cycling in the lpj dynamic global vegetation model, Global Change Biol., 9, 161185, 2003.

Skahill, B. E.: Use of the hydrological simulation program - fortran (hspf) model for watershed studies, System-wide Modeling, Assessment, Restoration and Technologies (SMART)/U.S. Army Engineer Research and Development Center (ERDC), 26, 2004.

Smith, R. A., Schwarz, G. E., and Alexander, R. B.: Regional interpretation of water-quality monitoring data, Water Resour. Res., 33, 2781-2798, 1997.

Sperna Weiland, F. C.: Hydrological impacts of climate change. Interpretation of uncertainties introduced by global models of climate and hydrology, PhD, Utrecht University, 2011.

Stanley, E. H., Fisher, S. G., and Grimm, N. B.: Ecosystem expansion and contraction: A desert stream perspective, Bioscience, 47, 427-435, 1997.

Stanley, E. H., Powers, S. M., and Lottig, N. R.: The evolving legacy of disturbance in stream ecology: Concepts, contributions, and coming challenges, J. N. Am. Bent. Soc., 29, 67-83, doi:10.1899/08-027.1, 2010.

Starr, R. C. and Gillham, R. W.: Denitrification and organic carbon availability in two aquifers, Ground Water, 31, 934-947, 1993.

Statzner, B. and Higler, B.: Stream hydraulics as a major determinant of benthic invertebrate zonation patterns, Freshw. Biol., 16, 127-139, 1986.

Steiger, J., Gurnell, A. M., and Goodson, J. M.: Quantifying and characterizing contemporary riparian sedimentation, River Res. Appl., 19, 335-352, 2003.

Stergiou, K. I. and Browman, H. I.: Bridging the gap between aquatic and terrestrial ecology, Mar. Ecol. Prog. Ser., 304, 271$307,2005$.

Sterner, R. W. and Elser, J. J.: Ecological stoichiometry: The biology of elements from molecules to the biosphere, Princeton University Press, Princeton, NJ, USA, 2002.

Stordal, M. C., Santschi, P. H., and Gill, G. A.: Colloidal pumping: Evidence for the coagulation process using natural colloids tagged with 203hg, Environ. Sci. Techn., 30, 3335-3340, 1996.

Strahler, A. N.: Dynamic basis of geomorphology, Geol. Soc. Am. Bull., 63, 923-938, 1952.

Stream Solute Workshop: Concepts and methods for assessing solute dynamics in stream ecosystems, J. N. Am. Benthol. Soc., 9, 95-119, 1990.

Struyf, E., Smis, A., Van Damme, S., Garnier, J., Govers, G., Van Wesemael, B., Conley, D. J., Batelaan, O., Frot, E., Clymans, W., Vandevenne, F., Lancelot, C., Goos, P., and Meire, P.: Historical land use change has lowered terrestrial silica mobilization, Nat. Commun., 1:129, doi:10.1038/ncomms1128, 2010.

Stumm, W.: The acceleration of the hydrogeochemical cycling of phosphorus, Water Res., 7, 131-144, doi:10.1016/00431354(73)90158-9, 1973

Syvitski, J. P. M., Vörösmarty, C. J., Kettner, A. J., and Green, P.: Impact of humans on the flux of terrestrial sediment to the global coastal ocean, Science, 308, 376-380, 2005.

Thorp, J. H. and Delong, M. D.: The riverine productivity model: An heuristic view of carbon sources and organic processing in large river ecosystems, Oikos, 70, 305-308, 1994.

Thorp, J. H., Thoms, M. C., and Delong, M. D.: The riverine ecosystem synthesis: Biocomplexity in river networks across space and time, River Res. Appl., 22, 123-147, 2006.

Turner, R. E., Rabalais, N. N., and Justic, D.: Gulf of mexico hypoxia: Alternate states and a legacy, Environ. Sci. Technol., 42 2323-2327, doi:10.1021/es071617k, 2008.

USEPA: Hydrological simulation program - fortran (HSPF), www. Epa.Gov/ceampubl/swater/hspf/, 2011.

Van Beek, L. P. H., Wada, Y., and Bierkens, M. F. P.: Global monthly water stress: 1. Water balance and water availability, Water Resour. Res., 47, W07517, doi:10.1029/2010wr009791, 2011.

Van de Wiel, M. J.: Numerical modelling of channel adjustment in alluvial meandering rivers with riparian vegetation, Department of Geography, University of Southampton, Southamptom, 2003.

Van Dijk, P. M., and Kwaad, F. J. P. M.: Modelling suspended sediment supply to the river rhine drainage network: A methodological study, Int. Assoc. Hydrol. Sci. Publ., 249, 165-176, 1998.

Van Drecht, G., Bouwman, A. F., Knoop, J. M., Beusen, A. H. W., and Meinardi, C. R.: Global modeling of the fate of nitrogen from point and nonpoint sources in soils, groundwater and surface water, Global Biogeochem. Cy., 17, 1115, doi:10.129/2003GB002060, 2003. 
Van Drecht, G., Bouwman, A. F., Harrison, J., and Knoop, J. M.: Global nitrogen and phosphate in urban waste water for the period 1970-2050, Global Biogeochem. Cy., 23, GB0A03, doi:10.1029/2009GB003458, 2009.

Van Rompaey, A., Verstraeten, G., Van Oost, K., Govers, G., and Poesen, J.: Modelling mean annual sediment yield using a distributed approach, Earth Surf. Proc. Land., 26, 1221-1236, 2001.

Van Vliet, M. T. H., Ludwig, F., Zwolsman, J. J. G., Weedon, G. P., and Kabat, P.: Global river temperatures and sensitivity to atmospheric warming and changes in river flow, Water Resour. Res., 47, W02544, doi:10.1029/2010WR009198, 2011.

Vannote, R. L., Minshall, G. W., Cummins, K. W., Sedell, J. R., and Cushing, C. E.: The river continuum concept, Can. J. Fish. Aquat. Sci., 37, 130-137, 1980.

Vaughan, I. P., Diamond, M., Gurnell, A. M., Hall, K. A., Jenkins, A., Milner, N. J., Naylor, L. A., Sear, D. A., Woodward, G., and Ormerod, S. J.: Integrating ecology with hydromorphology: A priority for river science and management, Aquatic Conservation, Mar. Freshw. Ecosyst., 19, 113-125, 2009.

Velthof, G. L., Oudendag, D., Witzke, H. P., Asman, W. A. H., Klimont, Z., and Oenema, O.: Integrated assessment of nitrogen losses from agriculture in eu-27 using miterra-europe, J. Environ. Qual., 38, 402-417, 2009.

Venohr, M., Donohue, I., Fogelberg, S., Arheimer, B., Irvine, K., and Behrendt, H.: Nitrogen retention in a river system and the effects of river morphology and lakes, Water Sci. Techn., 51, 1929, 2005.

Verstraeten, G., and Poesen, J.: Estimating trap efficiency of small reservoirs and ponds: Methods and implications for the assessment of sediment yield, Prog. Phys. Geogr., 24, 219-251, 2000.

Vidon, P. G. and Hill, A. R.: Landscape controls on the nitrate removal in stream riparian zones, Water Resour. Res., 40, W03201, doi:10.1029/2003WR002473, 2004a.

Vidon, P. G. F. and Hill, A. R.: Landscape controls on the hydrology of stream riparian zones, J. Hydrol., 292, 210-228, doi:10.1016/j.jhydrol.2004.01.005, 2004b.

Viviroli, D. and Weingartner, R.: The hydrological significance of mountains: from regional to global scale, Hydrol. Earth Syst. Sci., 8, 1017-1030, doi:10.5194/hess-8-1017-2004, 2004.

Vollenweider, R. A., Marchetti, R., and Viviani, R.: Marine coastal eutrophication, in, Elsevier, Amsterdam, 1310, 1992.

Vörösmarty, C. J., Meybeck, M., Fekete, B., Sharma, K., Green, P., and Syvitski, J. P. M.: Anthropogenic sediment retention: Major global impact from registered river impoundments, Global Planet. Change, 39, 169-190, 2003.

Walling, D. E.: The sediment delivery problem, J. Hydrol., 65, 209237, 1983.

Walling, D. E., Owens, P. N., Carter, J., Leeks, G. J. L., Lewis, S., Meharg, A. A., and Wright, J.: Storage of sedimentassociated nutrients and contaminants in river channel and floodplain systems, Appl. Geochem., 18, 195-220, 2003.

Walling, D. E.: Human impact on land-ocean sediment transfer by the world's rivers, Geomorphology, 79, 192-216, 2006.

Ward, J. V. and Stanford, J. A.: The serial discontinuity concept of lotic ecosystems, in: Dynamics of lotic ecosystems, edited by: Fontaine, T. D., and Bartell, S. M., Ann Arbor Science, Ann Arbor, 29-42, 1983.

Ward, J. V., Tockner, K., Uehlinger, U., and Malard, F.: Understanding natural patterns and processes in river corridors as the basis for effective river restoration, Regulated Rivers, Res. Manage., 17, 311-323, 2001.

Webster, J.: Analysis of potassium and calcium dynamics in stream ecosystems on three southern apalachian watersheds of contrasting vegetation, $\mathrm{PhD}$, University of Georgia at Athens, Athens, 1975.

Webster, J. R., and Meyer, J. L.: Organic matter budgets for streams: A synthesis, J. N. Am. Benthol. Soc., 16, 141-161, 1997.

Webster, J. R., Benfield, E. F., Ehrman, T. P., Schaeffer, M. A., Tank, J. L., Hutchens, J. J., and D'Angelo, D. J.: What happens to allochthonous material that falls into streams? A synthesis of new and published information from coweeta, Freshwater Biol., 41, 687-705, doi:10.1046/j.1365-2427.1999.00409.x, 1999.

Wen, L. S., Santschi, P. H., and Tang, D.: Interactions between radioactively labeled colloids and natural particles: Evidence for colloidal pumping, Geochim. Cosmochim. Ac., 61, 2867-2878, 1997.

Wendland, F., Blum, A., Coetsiers, M., Gorova, R., Griffioen, J., Grima, J., Hinsby, K., Kunkel, R., Marandi, A., Melo, T., Panagopoulos, A., Pauwels, H., Ruisi, M., Traversa, P., Vermooten, J., and Walraevens, K.: European aquifer typology: A practical framework for an overview of major groundwater composition at european scale, Environ. Geol., 55, 77-85, doi:10.1007/s00254-007-0966-5, 2008.

White, A. F., Schulz, M. S., Vivit, D. V., Blum, A. E., Stonestrom, D. A., and Harden, J. W.: Chemical weathering rates of a soil chronosequence on granitic alluvium: III. Hydrochemical evolution and contemporary solute fluxes and rates, Geochim. Cosmochim. Ac., 69, 1975-1996, 2005.

Whitehead, P. G., Wilson, E. J., and Butterfield, D.: A semidistributed integrated nitrogen model for multiple source assessment in catchments (INCA): Part I - model structure and process equations, Sci. Total Environ., 210-211, 547-558, 1998a.

Whitehead, P. G., Wilson, E. J., Butterfield, D., and Seed, K.: A semi-distributed integrated flow and nitrogen model for multiple source assessment in catchments (INCA): Part II - application to large river basins in south wales and eastern england, Sci. Total Environ., 210-211, 559-583, 1998b.

Wideín-Nilsson, E., Halldin, S., and Xu, C.: Global water-balance modelling with wasmod-m: Parameter estimation and regionalization, J. Hydrol., 340, 105-118, 2007.

Wood, E. F., Roundy, J. K., Troy, T. J., van Beek, L. P. H., Bierkens, M. F. P., Blyth, E., de Roo, A., Döll, P., Ek, M., Famiglietti, J., Gochis, D., van de Giesen, N., Houser, P., Jaffé, P. R., Kollet, S., Lehner, B., Lettenmaier, D. P., Peters-Lidard, C., Sivapalan, M., Sheffield, J., Wade, A., and Whitehead, P.: Hyperresolution global land surface modeling: Meeting a grand challenge for monitoring earth's terrestrial water, Water Resour. Res., 47, W05301, doi:10.1029/2010wr010090, 2011.

Yamazaki, D., Kanae, S., Kim, H., and Oki, T.: A physically based description of floodplain inundation dynamics in a global river routing model, Water Resour. Res., 47, W04501, doi:10.1029/2010WR009726, 2011.

Zhang, Y.-C., Slomp, C. P., Broers, H. P., Passier, H. F., and Van Cappellen, P.: Denitrification coupled to pyrite oxidation and changes in groundwater quality in a shallow sandy aquifer, Geochim. Cosmochim. Ac., 73, 6716-6726, 2009. 